\title{
RECONSIDERING CREDITOR GOVERNANCE IN A TIME OF FINANCIAL ALCHEMY
}

\author{
Jeremy McClane*
}

For many years corporate lenders have been a crucial force in the boardroom, providing a check on management and contributing to firm governance. However, as this Article documents, lenders' influence has receded in recent years for a large and important class of corporate borrowers. The culprit is a familiar one in a less familiar guise: the sale of loans by originating banks for securitization-like that which gained notoriety with pre-financial crisis mortgage-backed securities, but now are deployed in the market for corporate loans. As this Article points out, the shift from relationship lending to armslength securitization has the potential to intensify moral hazard, leading banks to provide less monitoring for their highly securitized clients. Recent data supports this narrative of debt governance dereliction with potentially enormous consequences: it heralds the disappearance of an important source of fiscal discipline and governance at a moment when U.S. corporations carry more debt than at any time in history (totaling half of U.S. gross domestic product), and an economic crisis

* Associate Professor of Law, University of Illinois College of Law. The author would like to thank Amitai Aviram, Adam Badawi, Bill Bratton, Albert Choi, Ofer Eldar, Jill Fisch, Gina-Gail Fletcher, Merritt Fox, Nadelle Grossman, Claire Hill, Cathy Hwang, Matthew Jennejohn, Kristin Johnson, Anita Krug, Travis Laster, Robert Lawless, Ann Lipton, Joshua Macey, Yaron Nili, Jordan Nyland, Frank Partnoy, Elizabeth Pollman, Adam Pritchard, Brian Quinn, Gabriel Rauterberg, Michael Sinkinson, Eric Talley, Robert Thompson, Verity Winship, and participants at the $2019 \mathrm{Na}$ tional Business Law Scholars Conference, and workshops at The University of Wisconsin, the University of Colorado, Indiana University and Tulane. Thanks especially to Mackenzie Humble, Dustin Graber and Shengling Zhu of the Columbia Business Law Review for excellent editorial work. All errors are my own. 
threatens to expose companies whose debt has been poorly managed.

This Article presents a theoretical and empirical examination of the dramatic change in creditor corporate governance and its implications. It shows how the diminishment of lenders' role in governance is a predictable result of a confluence of forces in the financial markets, in particular, the use of structured finance to securitize loans, which in turn has driven a lending market with diminishing checks on borrower profligacy. It also shows how this new market is weakening governance norms in ways that are harmful to borrowing companies, lenders, and society as a whole.

The Article makes two contributions to the literature. First, it empirically documents the decline of lenders' corporate governance interventions, cataloging original data on all borrower loan covenant violations - a primary mechanism by which lenders intervene in governance-from 2008 through 2018. Second, although many scholars have written about lenders' role in corporate governance and securitization separately, this Article brings the two together. It thereby adds a missing component to an important literature by showing how corporate governance and the financial system affect each other, and proposing solutions to bolster both.

I. Introduction 195

II. Background

A. Lenders' Role in Corporate Governance ..............203

1. Lenders and Agency Costs ..........................204

2. Lenders and Enhanced Firm Value ...............207

3. Lenders and Creditor-Shareholder Conflict ...209

B. Corporate Debt and Leveraged Loans

1. Changes in the Loan Market: From

"Originate-to-Hold" to "Originate-to-

Distribute"

2. Loan Covenants as Levers of Lender

Intervention

3. The Process of Lender Intervention: Waiver and Renegotiation 
4. Changes in the Leveraged Loan Market and the Erosion of Loan Covenants .....................2221

C. Structured Finance and Non-Bank Lenders ........225

1. Collateralized Loan Obligation Function and Form 226

2. From Risky Loans to Safe Securities: The Alchemy of CLOs .........................................2227

3. The Role of Lending Banks and Non-Bank Institutions.... 229

4. Shadow Banks and Changes in Creditor Incentives ..............................................2230

D. Securitization and Governance.........................2232

III. Empirical Case Study in Non-Governance: Data and Analysis ..........................................................2235

A. Loan and Covenant Violation Data .....................2237

B. Financial Proxies for Lender Intervention ...........244

1. Financial Conservatism ................................2245

2. Investment Conservatism .............................246

3. Operating Performance ................................2248

C. General Approach and Controls..........................248

D. Lender Intervention: Institutional Loans and CLO

Loans........................................................252

1. Basic Results: Raw Data .............................2255

2. Analysis of Data and Results ......................259

E. CEO/ Officer Turnover ......................................261

F. Robustness Checks of the Main Results ...............264

1. Comparisons of the Loans .............................2264

2. Non-Bank Loan Concentration ......................265

G. The Relationship Between Structured Finance and

Corporate Non-Governance ..............................267

IV. Discussion and Proposals ..........................................2272

A. Agency Costs and Shifting Corporate Governance 273

B. Intertwined Corporate Governance and Financial

Regulation.................................................2277

C. Ways to Address the Governance Effect of

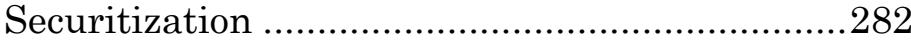

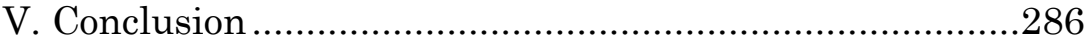




\section{INTRODUCTION}

Like many humans, corporate entities rely heavily on debt to finance their activities. And as with many humans, debt influences what companies are able to do. That corporate lenders play a critical role in the corporate governance ecosystem is well understood by scholars, who have long recognized the enormous power wielded by banks to discipline company managers and save firms from reckless financial decisions. ${ }^{1}$ However, this Article shows that recent trends are challenging the long-standing narrative. For an important and growing class of leveraged corporations, there is evidence that lenders' influence is becoming more tenuous than previously assumed. This is likely due to the fact that lender-initiated governance, unlike many other corporate managerial restraints, is driven by contract and therefore its outcomes are heavily determined by bargaining dynamics between lenders and borrowers. Those bargaining dynamics have dramatically shifted in borrowers' favor in recent years as non-bank lenders have begun to compete for leveraged borrowers' business, and securitizations have spurred demand for leveraged corporate loans. ${ }^{2}$

1 See e.g., Douglas G. Baird \& Robert K. Rasmussen, Private Debt and the Missing Lever of Corporate Governance, 154 U. PA. L. REV. 1209, 121617 (2006) (describing the provisions in loan agreements that give creditors a large role corporate management); George G. Triantis \& Ronald J. Daniels, The Role of Debt in Interactive Corporate Governance, 83 CALIF. L. REV. 1073, 1077-79 (1995) (discussing the role that creditors play in constraining agency costs, particularly with regard to managerial slack); Frederick Tung, Leverage in the Board Room: The Unsung Influence of Private Lenders in Corporate Governance, 57 UCLA L. REV 115, 117 (2009) [hereinafter Tung, Unsung Influence] (arguing that "banks and other private lenders exercise influence over firm management that is both routine and significant[,]" sometimes even exceeding that of shareholders and the board of directors); Joanna M. Shepherd et al., What Else Matters for Corporate Governance?: The Case of Bank Monitoring, 88 B.U. L. REv. 991, 994, 1001-06 (2008) [hereinafter Shepherd et al., What Else Matters] (analyzing how banks monitor corporate borrowers and reviewing the empirical evidence of bank monitoring activities).

2 See Frank Martin-Buck, Fed. Deposit Ins. Corp., Leveraged Lending and Corporate Borrowing: Increased Reliance on Capital Markets, With Important Bank Links, 13 FDIC Q. 41, 41 (2019) ("The migration of lending activity away from the regulated banking sector has increased competition 
This Article provides theory and evidence that suggests traditional lending relationships may no longer provide the incentives or leverage to constrain certain corporate borrowers. Banks that traditionally held long-term relationships with corporate borrowers now sell large portions of the loans they originate to securitization vehicles and other non-bank institutional investors. In theory, this practice may be vulnerable to the same problems that mortgage-backed securitization faced before the 2008 financial crisis: namely, lender moral hazard (a lack of incentive to guard against risks after the consequences have been distributed to others) and adverse selection (the disproportionate sale of risky loans to investors with less information about borrowers). However, as some scholars and industry watchers have pointed out, there are reasons to think that the lessons of 2008 have been learned and today's corporate loan market is not subject to the same problems. This Article assesses the competing possibilities and finds that, although many leveraged borrowers continue to show signs of lender monitoring, this stands in stark contrast to an important set of companies whose debt is primarily securitized that exhibit few, if any, indicia of lender intervention at critical moments when intervention has historically been apparent. Finally, the Article closes by discussing the implications of weakening lender engagement for policy and law.

To understand the kind of influence lenders can exert on corporate borrowers, consider Scott Livengood, the CEO of Krispy Kreme from 1998-2005. ${ }^{3}$ According to some, Livengood

for loans and facilitated looser underwriting standards and risky lending practices . . . ."). See also Fin. Stability BD., Vulnerabilities Associated WITH LEVERAGED LOANS AND COLLATERALISED LOAN OBLIGATIONS 8 (2019) [hereinafter FIn. STABILITY BD., VULNERABILITIES] ("The growth of covenantlite loans has been ascribed to a number of developments in the market ... likely driven by high availability of funding and competition for loan mandates by arrangers.”).

3 Mark Maremont \& Rick Brooks, Once-Hot Krispy Kreme Ousts Its CEO Amid Accounting Woes, WALL ST. J. (Jan. 19, 2005), https://www.wsj.com/articles/SB110605594997928805\#: :text=The\%20man\%20who\%20transformed $\% 20$ Krispy,woes $\% 20$ and $\% 20 a \% 20$ federal $\% 20$ probe [https://perma.cc/X8QU-RSF7]. 
was a model corporate leader and successfully took his company through a period of aggressive growth, expanding from a largely regional chain of donut shops to a nationwide phenomenon. ${ }^{4}$ Apart from his managerial vision, Livengood's loyalty to the brand was unparalleled. He even had his wedding cake made entirely out of Krispy Kreme donuts. ${ }^{5}$ In the last months of 2004, however, Krispy Kreme began to see disappointing results. ${ }^{6}$ A low-carb fad sweeping the country coupled with overly aggressive accounting dampened the company's fortunes and its stock price fell, resulting in securities litigation and Securities and Exchange Commission ("SEC") investigations $^{7}$ In short order, the board of directors fired Livengood and replaced him with a new CEO with a history at the helm of Enron, the failed energy business famous for committing one of the largest accounting frauds of the $21^{\text {st }}$ century. ${ }^{8}$ As many noted at the time, the move was hard to square with the prevailing understanding that boards generally don't fire a CEO after a few months of bad news, especially when the CEO had essentially hand-picked the board members himself. ${ }^{9}$ But the real force driving Livengood's ouster was not the directors or even the shareholders who nominally own the company; rather, the company's lenders had forced the move. ${ }^{10}$ Krispy Kreme had violated a covenant in a loan

4 See Andy Serwer, The Hole Story: How Krispy Kreme Became the Hottest Brand in America, FoRTUNE (July 7, 2003), https://archive.fortune.com/magazines/fortune/fortune_archive/2003/07/07/345535/index.htm [https://perma.cc/Z642-FGAM]. See also Baird \& Rasmussen, supra note 1, at 1209-10 (discussing the Krispy Kreme case).

5 See Maremount \& Brooks, supra note 3 ("His 2002 wedding included a cake made out of 720 doughnuts.").

6 See id.

7 See id. (reporting that "[a]s Krispy Kreme's growth began to slow [in early 2004], Mr. Livengood initially blamed the popularity of low-carbohydrate diets[,]" but accounting problems, aggressive expansion and an SEC investigation had also hampered the company).

8 See Press Release, Krispy Kreme Doughnuts, Inc., Krispy Kreme Announces Management Changes (Jan. 18, 2005); see also Baird \& Rasmussen, supra note 1 , at 1210 .

9 See e.g., Baird \& Rasmussen, supra note 1, at 1210.

10 See id. at 1210-11 (describing creditors' power to replace a CEO and suggesting that only creditor influence explains Livengood's firing). See also Maremount \& Brooks, supra note 3 ("Mr. Livengood's exit, decided during a 
agreement when it failed to send a quarterly report-a very small technical violation, but enough to give the lender de facto control over numerous important corporate decisions, including the choice of CEO. ${ }^{11}$

The Krispy Kreme example illustrates the power that lenders have historically had in corporate governance and for years such episodes have been routine, particularly when a borrower violates or comes close to violating a loan covenant. By virtue of these elaborate covenants, lenders have had enormous influence over corporate decisions including the choice of officers and board members, the issuance of dividends to shareholders, and the undertaking of major transactions. ${ }^{12}$ However, as this Article shows, there is evidence that this consequential corporate governance lever is waning. As scholars labor to understand the evolving impact of institutional investors, hedge funds, controlling shareholders and other corporate governance actors on the value of business enterprises, changes in the role of creditors should not be overlooked.

Scholars have noted the important role of creditors in influencing corporate management and constraining public company agency costs in theory, ${ }^{13}$ and empirical research has

Monday night board meeting that stretched past midnight, came as the company negotiated an extension until Jan. 24 on a $\$ 150$ million bank credit facility that has been in technical default since Friday.").

11 See Baird \& Rasmussen, supra note 1, at 1210-11.

12 See id. at 1211 (describing how loans contain "elaborate covenants covering everything from minimum cash receipts to timely delivery of audited financial statements. When a business trips one of the wires in a large loan, the lender is able to exercise de facto control rights-such as replacing the CEO of a company - that shareholders of a public company simply do not have"). See also Michael R. Roberts \& Amir Sufi, Renegotiation of Financial Contracts: Evidence from Private Credit Agreements, 93 J. FIn. ECON. 159, 166 (2009) ("For example, a borrower may wish to increase their capital expenditures, undertake an acquisition, alter their financial policy, increase dividends, liquidate assets, transfer money to subsidiaries, change their financial reporting procedure, alter collateral, consolidate assets, merge with another company, change lines of business, or modify their charter and bylaws. All of these activities may be explicitly restricted by credit agreements." (citation omitted)).

13 See, e.g., Triantis \& Daniels, supra note 1, at 1077-79 (discussing how lenders constrain managerial agency costs); Baird \& Rasmussen, supra note 1 , at $1211,1216-17$ (describing the "elaborate covenants" in loan 
found that lender intervention has a significant impact on firm performance. ${ }^{14}$ Lenders are able to exert their influence on borrowing companies through contractual provisions that allow them to monitor borrowers, constrain borrowers' actions, and intervene when borrowers show signs of trouble. ${ }^{15}$ Unlike the governance power held by shareholders and directors, which are defined by the relatively stable baseline of state corporate law and federal securities law, lenders' corporate governance influence flows from contract and therefore is heavily impacted by incentives and relative bargaining power. ${ }^{16}$

This reality cuts two ways. On the one hand, this means that lenders are able to secure more power over a firm's management than other stakeholders, such as shareholders or directors, particularly when firms are in financial distress. ${ }^{17} \mathrm{On}$ the other hand, it also means that lenders' power and incentives are driven by market forces, and both may have waned as lending practices have changed and competition has grown more intense. ${ }^{18}$ Competition has risen dramatically in the past

agreements that give creditors leverage); Tung, Unsung Influence, supra note 1, at 117 (explaining that banks exert influence on corporations that is as or more important than that exercised by other corporate stakeholders).

14 See Greg Nini et al., Creditor Control Rights, Corporate Governance, and Firm Value, 25 REV. Fin STUD. 1713, 1733-47 (2012) [hereinafter Nini et al., Creditor Control Rights] (providing empirical evidence that lenders intervene in borrowers' affairs at critical times).

15 See Baird \& Rasmussen, supra note 1, at 1211.

16 I recognize that the ability of shareholders and other company stakeholders to influence company management is also dependent on bargaining power to some degree, and that state corporate law allows many shareholder and director rights to be tailored or curtailed. Nonetheless, the default provisions of the law provide a starting point, and in most cases, a fallback position that these stakeholders have regardless of their bargaining power.

17 See Baird \& Rasmussen, supra note 1, at 1216-17 (noting that lenders can structure their loan agreements to retain broad powers that are generally reserved for shareholders, such as cash flow and control rights); see also Tung, Unsung Influence, supra note 1, at 117.

18 See, e.g., Aaron Weinman, US Investors Sound Alarm Over Projected Add-Backs, REUTERs (May 9, 2019), https://www.reuters.com/article/investors-addbacks/us-investors-sound-alarm-over-projected-add-backsidUSL2N22L1MK [https://perma.cc/7ZGH-9U89] ("So long as investor demand is superior, these looser borrowing terms will persist . ...”). 
ten years in the market for leveraged loans-those made to companies that already have significant levels of debt, and therefore have credit ratings below investment grade. ${ }^{19}$ As of 2019 , approximately $70 \%$ of U.S. companies fell into this category, including well-known firms such as Burger King, Chrysler, Dell, American Airlines, and Avis. ${ }^{20}$ Competition has increased in tandem with changes in lending practices. Fewer loans are held entirely by their originating relationship banks-rather, the majority are now sold to non-bank financial institutions: hedge funds, mutual funds, insurance companies and structured finance vehicles. By the end of 2019, non-bank financial institutions accounted for more than $90 \%$ of the $\$ 1.2$ trillion leveraged loan market. ${ }^{21}$ Between one-half and two-thirds of those loans are securitized and sold to investors as collateralized loan obligations ("CLOs") — structured finance vehicles that hold portfolios of leveraged debt. ${ }^{22}$

One might predict that non-bank financial institutions, and in particular CLOs, would have far less incentives than relational lenders to monitor corporate borrowers or intervene when borrowers run into trouble because they hold diversified portfolios of debt, and CLOs have essentially repackaged the risk of loans' default and sold it to investors in the market. ${ }^{23}$ Moreover, one might predict that relational lenders may have less ability or incentive to police borrowers when they retain only small portions of a borrower's debt, because the risk they retain on the borrower's default is small. Additionally, competition with other lenders for the borrower's business may lead relational lenders to be more solicitous even if they technically have power to influence the borrower.

19 See discussion infra Section II.B.

20 See Kenneth E. Bentsen, Jr., Leveraged Loans - A Small but Important Piece of the US Financial System, SEc. InDUS. \& Fin. MKTS. Ass'N (Apr. 9, 2019), https://www.sifma.org/resources/news/leveraged-loans-asmall-but-important-piece-of-the-us-financial-system [https://perma.cc/7UGY-VA3Y].

21 See S\&P Global, Six Key Risks In LeVERAGEd Lending For FinaNCIAL InsTITUTIONs 2, 4 (2018), https://www.allnews.ch/sites/default/files/files/20181127_SP_Six-Key-Risks-In-Leveraged-Lending-For-Financial-Institutions.pdf [https://perma.cc/U7WK-L2ZA].

22 See id. at 4-5.

23 For further description of CLOs, see infra Section II.C. 
However, one might also reasonably assume that relational lenders continue to monitor and intervene because they value their ongoing relationships with borrowers. Recent research suggests that bank lenders continue to retain a significant interest in borrowers' loans even after the majority of the loans have been securitized or sold to non-bank institutions. ${ }^{24}$ The retained portions of these loans continue to be governed by contracts that often retain full monitoring powers, despite the trend toward less lender protection, typified by so-called "cov-lite" loans. ${ }^{25}$ Moreover, non-bank lenders may take an interest in borrower behavior even in the absence of a direct relationship.

This Article investigates these possibilities. The analysis begins by identifying all of the reported loan covenant violations for public borrowers from 2008 through 2018-instances in which, as the Krispy Kreme example illustrates, corporate lenders have the most power and incentive to assert themselves in corporate management. It shows that governance intervention continues to occur for many borrowers, but for companies whose loans are primarily securitized, the past ten years have seen a dramatic, but largely unnoticed, decline in lenders' influence.

Specifically, the analysis below provides evidence that relational lenders-banking institutions that have ongoing relationships with their clients - continue to intervene in many borrowing firms' affairs when a covenant is violated or waived. On average, those interventions result in more responsible firm financial management, as measured by a number of financial metrics. ${ }^{26}$ Firms that violate covenants are also more likely to see their CEO suddenly depart after the violation, suggesting that lenders are not shy about exerting their influence to shakeup a company's management team. ${ }^{27}$

24 See Mitchell Berlin et al., Concentration of Control Rights in Leveraged Loan Syndicates, J. FIN ECON. (forthcoming 2020) (manuscript at 2-3), https://papers.ssrn.com/sol3/papers.cfm?abstract_id=2960757 [https://perma.cc/J2YC-SDQY].

25 See id.

26 See discussion infra Part III.

27 See discussion infra Part III. 
This Article shows a contrasting picture for leveraged loan borrowers whose debt is primarily securitized. In particular, the data shows that corporate borrowers whose loans are primarily packaged into CLOs tend to see far lower levels of beneficial creditor intervention even after a covenant violation. The same financial metrics that improve for relational lending covenant violators either fail to improve or languish for covenant violators whose loans are packaged into CLOs.

There is also evidence that securitized borrowers experience less lender intervention to change a company's CEO, CFO, or President, in contrast to other borrowers for whom lenders' influence in replacing high level managers remains evident. These findings suggest an echo of the moral hazard problem that beset securitization markets leading up to 2008 . This, coupled with a possible loss of bargaining power at a time of intense competition for loans, results in creditors who are unable or unwilling to fulfill the role they are presumed to play in the governance of a large and growing number of corporate borrowers.

The rest of this Article proceeds as follows. Part I describes leveraged loans, loan covenants, non-bank lenders and CLOs. It also describes the literature that has studied lender corporate governance in the past, and develops hypotheses based on prior research. Part II describes the data and presents the results of the empirical analysis. Part III discusses several proposals for addressing the issues raised in the Article.

\section{BACKGROUND}

Over the past decade, a transformation has occurred in the corporate lending market. While this market used to be dominated by banks cultivating important relationships with corporate borrowers, today it has become a market dominated by relatively remote sources of capital which borrowers have few or no direct ties to. Background information on this market, and on lenders' role in corporate governance, is important for understanding these changes. This Part begins with a summary of the issues surrounding lender intervention in corporate governance, gives background on the market for corporate loans, and discusses how non-bank lending, and in 
particular, the financial alchemy of CLOs, affects both lending and governance.

\section{A. Lenders' Role in Corporate Governance}

Corporations rely on debt to finance their activities. ${ }^{28}$ Broadly speaking, corporate debt takes one of two forms: bank loans memorialized in contracts between lenders and corporate borrowers, and debt securities such as bonds that can be traded among investors. ${ }^{29}$ Bonds, like other kinds of securities, are relatively impersonal; investors have little direct relationship with borrowers and can usually only affect the borrower as part of large group, or if they hold a high percentage of the face value of the bonds. ${ }^{30}$ Loans (at least historically speaking) tend to be different in that lenders maintain an ongoing contractual relationship with the lender. ${ }^{31}$ Lenders often include covenants in their contracts that allow them to monitor borrowers by, for example, requiring periodic reports, and setting limits on how much future debt a company can take on before effectively being required to get permission from the lender. ${ }^{32}$ Loans also frequently restrict borrower behavior by requiring the lender's permission to acquire large

28 See Mayra Rodriguez Valladares, U.S. Corporate Debt Continues to Rise As Do Problem Leveraged Loans, ForBes (July 25, 2019), https:/www.forbes.com/sites/mayrarodriguezvalladares/2019/07/25/u-scorporate-debt-continues-to-rise-as-do-problem-leveraged-loans [https://perma.cc/XRL3-WVTA] (stating that "total US corporate debt is $\$ 15.5$ trillion, $74 \%$ of US GDP”).

29 See William W. Bratton, Bond Covenants and Creditor Protection: Economics and Law, Theory and Practice, Substance and Process 7 Eur. Bus. ORG. L. REV. 39, 68 (2006) (explaining the uses of corporate bonds and loans and stating that "[d]ebt contracts, both public and private, typically permit covenants to be amended or waived by a majority (simple or twothirds of principal amount) of the holders thereunder. Given a large number of holders, this means a formal proxy solicitation, usually made on a takeit-or-leave-it basis without negotiation. Such dispersed bondholders, like shareholders, can suffer the classic collective action problem" (footnote omitted)).

30 See id. at 44.

31 Id.

32 Id. at $49-58$. 
stakes in other companies, or to make large capital expenditures. ${ }^{33}$

While these provisions themselves constrain corporate borrowers' behavior, lenders have an additional potent lever. When a borrower violates one of these covenants, for example, by allowing its debt-to-equity ratio to exceed the limit set in the loan contract, the lender acquires the right to accelerate repayment (i.e., ask for immediate payment of the loan's principal and interest). ${ }^{34}$ Lenders rarely invoke this right in reality, as borrowers could seldom actually repay on such an accelerated basis and may risk ending up in bankruptcy if they attempted to do so. ${ }^{35}$ Bankruptcy is an undesirable outcome for the lender as well as the borrower, because it can tie up company assets, hinder the company's operations, and result in the lender sacrificing a portion of its claim. Instead, lenders typically waive these covenant violations and renegotiate the loan agreement in exchange for remedial action by the borrower according to the lender's wishes. ${ }^{36}$ Lenders' waiver and renegotiation gives them substantial influence in corporate governance. ${ }^{37}$ This governance influence has been both theorized by scholars, ${ }^{38}$ and documented in quantitative empirical studies, ${ }^{39}$ as further explained below.

\section{Lenders and Agency Costs}

Scholars have found that lenders fulfill an important role in the corporate governance ecosystem by influencing agency costs, a primary focus of corporate law. ${ }^{40}$ Agency costs arise

33 Id. at $54-57$.

34 Id. at 54, 57-58.

35 Id. at 54.

36 See Nini et al., Creditor Control Rights, supra note 14, at 1715.

37 Id. See also Baird \& Rasmussen, supra note 1, at 1210-11.

38 See, e.g., Triantis \& Daniels, supra note 1, at 1082-90; Baird \& Rasmussen, supra note 1, at 1216-17.

39 See Nini et al., Creditor Control Rights, supra note 14, at 1715-17, 1720-46; Shepherd et al., What Else Matters, supra note 1, at 994-96, 101320, 1027-39.

40 See Triantis \& Daniels, supra note 1, at 1074, 1082; see also Michael C. Jensen \& William H. Meckling, Theory of the Firm: Managerial Behavior, Agency Costs and Ownership Structure, 3 J. FIn. Econ. 305, 308-09 (1976). 
from the separation of ownership and control-that is, when the interests of shareholder-owners diverge from the interests of corporate manager-agents. ${ }^{41}$ Shareholders, who generally delegate the responsibility of managing the firm to others, might worry that the managers will serve their own interests at the expense of firm value. ${ }^{42}$ This may happen for a number of reasons: management's desire to entrench itself, a pursuit of excessive compensation, ${ }^{43}$ overconsumption of corporate perquisites, a bias towards empire building, ${ }^{44}$ or simple incompetence. Remedying these agency costs is often seen as the goal of corporate governance. ${ }^{45}$ The mechanisms for doing so

41 The separation of ownership and control was famously observed by Berle and Means. See generally Adolf A. Berle, JR. \& Gardiner C. MEAns, The Modern Corporation And Private Property (1932). The basic agency cost problem has been the subject of a large body of scholarship ever since. See, e.g., Jensen \& Meckling, supra note 40, at 308; Eugene F. Fama \& Michael C. Jensen, Separation of Ownership and Control, 26 J. L. \& ECON. 301, 301-02 (1983) (exploring agency costs in corporate entities); Zohar Goshen \& Richard Squire, Principal Costs: A New Theory for Corporate Law and Governance, 117 CoLUM. L. REV. 767, 767 (2017) ("For the last forty years, the problem of agency costs has dominated the study of corporate law and governance."); Leo E. Strine Jr., Toward Common Sense and Common Ground? Reflections on the Shared Interests of Managers and Labor in a More Rational System of Corporate Governance, 33 J. CORP. L. 1, 6 (2007) (describing corporate law scholars as "fetishiz[ing] the agency costs that flow from the separation of ownership and control").

42 See Triantis \& Daniels, supra note 1, at 1074; see also StePhen M. BAINBRIDGE, CORPORATION LAW AND ECONOMICS 193 (2002) (explaining that under corporation statutes "the board acts and shareholders, at most, react"); Stephen M. Bainbridge, Director Primacy and Shareholder Disempowerment, 119 HARV. L. REV. 1735, 1735 (2006) ("[T] he extent to which corporate law is stacked against shareholder 'intervention power' goes beyond just the housekeeping rules; much of business law acts to limit shareholder involvement in corporate governance.”).

43 See Yaron Nili, Successor CEOs, 99 B.U. L. REV. 787, 812 (2019) ("Decreased oversight and evaluation of management has the undesired effect of CEO-chairs further entrenching their position and can lead to excessive compensation.").

44 See Triantis \& Daniels, supra note 1, at 1078 ("[O]ther stakeholders know that the imposition of fixed obligations under the loan agreement forces managers to disgorge free cash rather than use it to bankroll forms of managerial slack (for example, managerial perks or empire building).”).

45 See Goshen \& Squire, supra note 41, at 767. 
can be divided into internal and external disciplinary forces. ${ }^{46}$ Internal governance forces consist of a company's directors (especially independent directors), ${ }^{47}$ shareholder proposals, ${ }^{48}$ the proxy voting process, ${ }^{49}$ and fiduciary duties imposed by state corporate law. ${ }^{50}$ External forces include the capital markets, ${ }^{51}$ the market for corporate control, ${ }^{52}$ and the product market in which the firm operates. ${ }^{53}$ Lenders enter this picture as external stakeholders who influence some of the internal ones, ideally monitoring management and helping to mitigate the agency cost problem, but potentially creating agency costs of their own.

This intervention is often described as a benefit to corporations, ${ }^{54}$ although there are valid arguments that lenders create conflicts that reduce firm value. These possibilities, discussed below, largely depend on circumstances and which stakeholder's perspective one chooses to take. I note, however,

46 See id. at 1075-76.

47 Id. at 1075; see also Gregory H. Shill, The Golden Leash and the Fiduciary Duty of Loyalty, 54 UCLA L. REV. 1246 (2017) (arguing that a renewed independent director compensation arrangement could reduce corporate agency costs).

48 Triantis \& Daniels, supra note 1, at 1075.

49 Id.

50 Id. at 1075; see also Frank H. Easterbrook \& Daniel R. Fischel, Contract and Fiduciary Duty, 36 J. L. \& ECON. 425, 426-27 (1993).

51 Triantis \& Daniels, supra note 1 , at 1075-76.

52 Id.; see also Henry G. Manne, Mergers and the Market for Corporate Control, 73 J. PoL. ECON. 110, 113 (1965) ("Only the take-over scheme provides some assurance of competitive efficiency among corporate managers and thereby affords strong protection to the interests of vast numbers of small, non-controlling shareholders."). Corporate takeovers became an important mechanism of corporate discipline, as well as a source of perceived abuses during the 1980s when many such transactions were facilitated by the issuance of high-yield ("junk") bonds. See, e.g., Frank H. Easterbrook \& Daniel R. Fischel, The Proper Role of a Target's Management in Responding to a Tender Offer, 94 HARV. L. REV. 1161, 1169-73 (1981) (describing tender offers as one method of monitoring managerial behavior); Roberta Romano, A Guide to Takeovers: Theory, Evidence, and Regulation, 9 YALE J. REG. 119, 129-31 (1992) (discussing how takeovers discipline managerial misbehavior).

53 Triantis \& Daniels, supra note 1 , at 1075-76.

54 See e.g., Nini et al., Creditor Control Rights, supra note 14, at 171315. 
that regardless of whether the net effect of lender intervention is good or bad, it is an important force in corporate governance.

\section{Lenders and Enhanced Firm Value}

There are a number of ways in which lender influence can lead to increased value for stakeholders in a corporate enterprise. One way that scholars have framed the benefits of lender intervention espouses a theory of interactive corporate governance. ${ }^{55}$ According to this theory, both equity and debt holders have a common interest in containing agency costs generated by the separation of managers and owners. ${ }^{56}$ Under this theory all stakeholders benefit from mechanisms that discipline management to be financially responsible, take appropriate (but not outsized) risks, and restrict wastefulness (sometimes referred to as managerial "slack"). ${ }^{57}$ In a similar vein, other scholars have noted that lenders have expertise with regard to debt management and fiscal responsibility, and that they bring their proficiency to bear when interacting with internal corporate stakeholders. ${ }^{58}$

Lender interaction with internal stakeholders can be helpful (from the standpoint of agency costs and overall firm value) because shareholders' ability to constrain management is sometimes limited by collective action problems - the reality that numerous dispersed shareholders do not have the ability or incentive to coordinate and monitor management. ${ }^{59}$ In such circumstances, creditors have more incentive to monitor

55 See Triantis \& Daniels, supra note 1, at 1079-80.

56 See id. at 1079.

57 Id. at 1074, 1077-78; see also Nini et al., Creditor Control Rights, supra note 14 , at $1716-17$.

58 See Nini et al., Creditor Control Rights, supra note 14, at 1716-17. See also Shepherd et al., What Else Matters, supra note 1, at 1002 ("The detailed reporting obligations and contract constraints imposed by the loan agreement, as well as the bank's ability to control the borrower's cash, enable the bank literally to control the firm.").

59 See Easterbrook \& Fischel, supra note 52, at 1169-71. Collective action problems arise when the value of shareholders' stake is smaller than the cost of their coordination. In such a case, if shareholders do not like what management is doing, it is less costly simply to sell their stock. See id. 
management, and can do so at a relatively lower cost than shareholders through contractual covenants. ${ }^{60}$

In addition, creditors might theoretically have more incentive to care about the long-term performance of a corporate borrower due to relational and reputational concerns. ${ }^{61}$ Unlike public company shareholders, who can exit their relationships with a corporation at any time by selling their shares, or bond market investors who can sell their bonds, bank lenders have historically had longer term, repeat-player relationships with corporate borrowers and thus have had a stake in borrowers' long-term success. ${ }^{62}$

Empirical research supports the theory that lenders interact with borrowing companies to improve their performance in a way that is often consistent with the interests of other corporate stakeholders. ${ }^{63}$ Specifically, a number of rigorous studies have found that lender monitoring and intervention leads to positive changes in firm performance. ${ }^{64}$ Moreover, there is scant evidence that lender intervention leads to increased conflicts of interest with shareholders, or at least, conflicts in which the agency costs outweigh the positive benefits

60 See Triantis \& Daniels, supra note 1, at 1087-88; see also Nini et al., Creditor Control Rights supra note 14, at 1715-16, 1747.

61 See Triantis \& Daniels, supra note 1, at 1092.

62 See id. at 1079-80, 1104-07 ("In this sense, the interactive theory is true to the contractual vision of the firm and yields a system that is in fact far more effective in disciplining and correcting managerial slack than the traditionally conceived model in which shareholders act as the sole principals for management.").

63 See Nini et al., Creditor Control Rights, supra note 14, at 1716-17, $1747-58$.

64 See, e.g., See Nini et al., Creditor Control Rights, supra note 14, at 1716-17; Shepherd et al., What Else Matters, supra note 1, at 993-94; Matthew T. Billett et al., The Effect of Lender Identity on a Borrowing Firm's Equity Return, 50 J. FIN. 699, 717 (1995) (finding positive abnormal stock returns to borrowing firms following the disclosure of bank loans from banks perceived as good monitors); Christopher James, Some Evidence on the Uniqueness of Bank Loans, 19 J. FIN. ECON. 217, 225 (1987) (finding positive stock impacts for borrowers following the announcement of a new bank loan contract); Dianna C. Preece \& Donald J. Mullineaux, Monitoring by Financial Intermediaries: Banks vs. Nonbanks, 8 J. Fin. SERVs. REs. 193, 200-01 (1994) (finding that borrowing companies experience positive abnormal stock returns upon announcing loan contracts with non-bank lenders). 
of intervention. ${ }^{65}$ To the contrary, the research suggests that lenders play an important role in disciplining management when other governance mechanisms cannot. ${ }^{66}$ However, there are circumstances in which one might expect lenders' interests to diverge from those of other stakeholders, potentially destroying value for those stakeholders, as discussed below.

\section{Lenders and Creditor-Shareholder Conflict}

The benefits that lenders bring to corporate governance might be tempered by the fact that their interests are sometimes in tension with those of other stakeholders. Scholars have described the conflict between the interests of equity holders and those of debt holders, ${ }^{67}$ and in theory, lender intervention might sharpen that conflict. Lenders are assumed to be more risk averse than equity holders, since they stand to suffer greater downside losses from risky projects that drain resources that would be otherwise available for debt repayment. ${ }^{68}$ Equity holders, on the other hand, are subordinate to creditors in the capital structure; when the firm's value is low, shareholders are in the same position whether resources are used to pay debt or to invest in a risky project-in either case, the firm's remaining money is not going to them. ${ }^{69}$ Thus, in theory equity holders have nothing to lose and possibly something to gain by taking a chance on a high-risk, high-reward

65 See, e.g., Nini et al., Creditor Control Rights, supra note 14, at 171617; Shepherd et al., What Else Matters, supra note 1, at 993-94; Triantis \& Daniels, supra note 1 , at 1079, 1091, 1111-12. Nonetheless, one recent study has found evidence that lenders refrain from intervening to reduce borrowers' debt load or investment expenditures when the lender also happens to be a shareholder of the borrower, suggesting a possible tradeoff between equity and debt holder interests. See Sudheer Chava et al., Covenants, Creditors' Simultaneous Equity Holdings, and Firm Investment Policies, 54 J. Fin. \& QuANTITATIVE ANALYsis 481, 481-83 (2019).

66 See Triantis \& Daniels, supra note 1, at 1079, 1091, 1082-88.

67 See, e.g., Jensen \& Meckling, supra note 40, at 333-37; Bratton, supra note 29 , at 50 .

68 See id. at 333-37; see also Gary Gorton \& James Kahn, The Design of Bank Loan Contracts, 13 REv. FIn. STUD. 331, 342 (2000) (noting that when borrowing companies' equity value is low enough relative to its debt, "the borrower may have an incentive to switch projects to add risk").

69 Id. 
project, even though a poor result will mean a loss for the company's lenders. ${ }^{70}$

Thus, when creditors intervene they have an incentive to act conservatively and stymie projects they view as excessively risky, even if those projects have a positive net present value. In other words, lenders might block projects that are likely to result in more gains than losses, in present value terms. ${ }^{71}$ Alternatively, lenders may reduce firm value by intervening too aggressively when a borrower violates a financial covenant. For instance, a lender may require too many concessions, insist on the dismissal of an otherwise competent $\mathrm{CEO},{ }^{72}$ or simply extract burdensome terms from the borrower in a loan renegotiation in exchange for waiving the default and refraining from accelerating repayment. ${ }^{73}$ Moreover, lenders often have an incentive to limit payouts to shareholders in the form of dividends and share buybacks. ${ }^{74}$ Lenders do this to ensure that cash that would otherwise be used to pay off debt does not leave the firm. ${ }^{75}$ This preference potentially conflicts with the interests of equity holders, as it might be in a shareholder's short-term interest to receive a payout from

70 This is purported to be particularly true with respect to debtor corporations who are close to insolvency. See, e.g., Credit Lyonnais Bank Nederland, N.V. v. Pathe Commc'ns. Corp., No. 12150, 1991 WL277613, at *34 n.55 (Del. Ch. Dec. 30, 1991) (discussing the fiduciary duties of directors to creditors when a corporation is in the "vicinity of insolvency"). To illustrate, if a debtor firm close to insolvency has two opportunities, one with high risk of loss but high potential payout, and one with low risk of loss but low potential payout, the creditors-who stand to lose the value of their investment if the high-risk gamble goes poorly and the firm goes insolvent - will want to firm to take the less risky route, ensuring they can be repaid even if the company and equity holders are is left with little money. The equity holders, however, will prefer the riskier option, since they have less to lose and more to gain from doing so. Since they stand to lose everything in most scenarios, equity holders would prefer to take the chance, however slim, of a large payout. The interests of equity holders and debt holders are thus potentially adverse in some situations.

71 See Nini et al., Creditor Control Rights, supra note 14, at 1747.

72 See Baird \& Rasmussen, supra note 1, at 1210-11.

73 See, e.g., Roberts \& Sufi, supra note 12 , at 166-69.

74 See Bratton, supra note 29 , at 50.

75 Id. 
the company even if it comes at the expense of long-term debt repayment. ${ }^{76}$

Settling the debate over these conflicts and the tradeoff between long term and short-term value is a larger undertaking than cannot be adequately executed by way of a background discussion. Nor does this Article purport to resolve whether the actions lenders take create overall positive or negative results for firms. For present purposes, it is important to see the incentives that lenders have and the various forms their interventions may take, as they play a significant role alongside other actors affecting corporate governance. To that end, it is likewise necessary to understand how lenders' influence might change as the market for debt changes.

\section{B. Corporate Debt and Leveraged Loans}

An important trend potentially affecting lenders' influence in firm governance in recent years is the expansion of the leveraged loan market, which in turn is driven by the increased involvement of non-bank institutional lenders and the expansion of loan securitization. Leveraged loans are a staple of corporate finance, providing an important means for corporations to obtain funding for their day-to-day operations, as well as for M\&A activity and leveraged buyouts. ${ }^{77}$ The term "leveraged" refers to the fact that borrowers in these types of arrangements typically have high levels of debt, and therefore have credit ratings below investment grade. ${ }^{78}$ This means that

76 Id.

77 See Glenn Yago \& Donald McCarthy, Milken Inst., The U.S. LeVERAGED LOAN MARKET: A PRIMER 14-18, 19 fig.10 (2004), https://assets1c.milkeninstitute.org/assets/Publication/ResearchRe-

port/PDF/loan_primer_1004.pdf [https://perma.cc/QT34-5JY4] (describing the evolution of the leveraged loan market and providing statistics on syndicated loans' use by corporate borrowers); Leveraged Loan Primer, STANDARD \& POOR'S GloB. MKT. InTELligence, (2019), https://www.spglobal.com/marketintelligence/en/pages/toc-primer/lcd-primer\#sec2 [https://perma.cc/ZWS4-V92F] ("The global leveraged loan market has grown . . . to become a full-fledged asset class and an indispensable component of the corporate finance, $\mathrm{M} \& \mathrm{~A}$, and leveraged buyout landscapes.").

78 See YAGO \& MCCARThY, supra note 77, at 11-12. 
their ability to repay is more speculative than "investment grade" borrowers, making them attractive to lenders looking to charge higher interest rates. ${ }^{79}$ Despite its implicit riskiness, leveraged borrowing is quite common, with $70 \%$ of U.S. corporations fitting the definition of leveraged borrowers. ${ }^{80}$ As the supply of credit has grown, the market for leveraged loans has ballooned from $\$ 497$ billion in 2010 to over $\$ 1.15$ trillion by the end of $2018 .{ }^{81}$

\section{Changes in the Loan Market: From "Originate- to-Hold" to "Originate-to-Distribute"}

With the growing number of leveraged borrowers, the market for leveraged loans has undergone significant changes in recent years. Before 2010, a typical loan transaction involved the borrower (or, "issuer") appointing a lead bank, (also known as an "arranger"). ${ }^{82}$ Usually, the arranger was a large commercial or investment bank, often selected in a competitive bidding process, but could also be selected by virtue of its preexisting relationship with the borrower. ${ }^{83}$ To share the credit

79 See id. at 11. Although different sources define leveraged loans slightly differently, a leveraged loan typically has an interest rate higher than 150 basis points ("bps") over the London Interbank Offered Rate ("LIBOR"), which is a benchmark market interest rate used for many types of financing. See id. at 5, 11-12. Some market participants define leveraged loans exclusively in relation to their interest rate. For instance, the rating agency Standard \& Poor's ("S\&P") defines a loan as leveraged if it has an interest rate of $125 \mathrm{bps}$ or more above LIBOR. Id. at 12. Loans with a margin (interest rate) of 500 bps or more above LIBOR are sometimes referred to colloquially as "high-octane" loans. Id. Credit ratings also determine whether a loan is leveraged, by some definitions. Ratings assigned by credit rating agencies such as Moody's, Fitch, and S\&P range from the highest investment grade (AAA for S\&P and Fitch, Aaa for Moody's) to those below investment grade $(\mathrm{BB}+$ and lower for $\mathrm{S} \& \mathrm{P}$ and Fitch, Ba1 and below for Moody's). Id. at 11-12; see also Moody's InV'Rs SERV., RATING Symbols AND DEFINITIONS 6 (2020).

80 See Sec. Indus. \& Fin. Mkts. Ass'n, Leverage Lending FAQ \& FACT SHEET 3 (2019), https://www.sifma.org/wp-content/uploads/2019/03/Leverage-Lending-FAQ.pdf [https://perma.cc/NQC6-BMKD].

81 Leveraged Loan Primer, supra note 77.

82 See Fin. STABility Bd., Vulnerabilities, supra note 2, at 3; Tung, Unsung Influence, supra note 1, at 163.

83 See Fin. Stability BD., Vulnerabilities, supra note 2, at 3; Tung, 
risk of the loan, arrangers often syndicated loans by finding other banks willing to become lenders. ${ }^{84}$ The lead bank performed due diligence on the borrower, analyzed the borrower's credit and negotiated the loan terms, including the covenants, which provide the mechanism for influencing corporate governance. ${ }^{85}$ The lead bank also acted as an agent for the lending syndicate, policing violations of the loan covenants and deterioration in the borrower's financial condition. ${ }^{86}$ In the event of a violation, the lead bank advised the rest of the syndicate on the appropriate course of action, and in some cases, had plenary power to waive the violation and renegotiate the loan. ${ }^{87}$ Although the loans could be traded, they were relatively illiquid compared to debt securities like bonds, because transferring an interest in the loan required assigning rights under the contract, a process that often required the permission of the borrower, some percentage of the other lenders in

Unsung Influence, supra note 1, at 163, 165.

84 See Elisabeth de Fontenay, Do the Securities Law Matter? The Rise of the Leveraged Loan Market, 39 J. CoRP. L. 725, 740 (2014) ("This is how the practice of loan syndication and secondary trading arose and quickly became the world's largest source of corporate financing. With loan syndication, a major bank referred to as the lead arranger negotiates the key terms of the loan with the borrowing company, and then organizes a syndicate of lenders to fund it." (footnote omitted)). See also YAGO \& MCCARTHY, supra note 77 , at 7 .

85 See Tung, Unsung Influence, supra note 1, at 163; see also Katerina Simons, Why Do Banks Syndicate Loans?, 1993 New England ECON. REV. 45, 46 (1993) (explaining that the "lead bank[] acts as syndicate manager, recruiting a sufficient number of other banks to make the loan, negotiating details of the agreement, and preparing documentation").

86 See Tung, Unsung Influence, supra note 1, at 163 ("It takes the lead in administering the loan, monitoring the borrower and communicating with firm management on behalf of the syndicate, and disseminating information within the syndicate. When a borrower violates a covenant or defaults, the lead bank plays a central role in investigating and recommending a course of action to the syndicate." (footnote omitted)).

87 See Amir Sufi, Information Asymmetry and Financing Arrangements: Evidence from Syndicated Loans, 62 J. Fin. 629, 633 (2007) ("During the life of the loan, the lead arranger typically also acts as the 'agent' bank that monitors the [borrowing] firm, governs the terms of the loan, administers the drawdown of funds, calculates interest payments, and enforces financial covenants.”). 
the syndicate, or both. ${ }^{88}$ Moreover, the trading market for these loans was limited to banking institutions. ${ }^{89}$ This model of leveraged lending is generally referred to as the "originateto-hold" model, because originating lenders usually held the loans themselves to maturity. ${ }^{90}$

In the years leading up to the 2008 financial crisis, the originate-to-hold model began to give way to the "originate-todistribute" one, as a growing class of non-bank investors took an interest in leveraged loans, creating a robust trading market for them. ${ }^{91}$ The majority of these non-bank investors were CLOs-financial vehicles created to transform pools of risky loans into less risky securities ${ }^{92}$ _but also included some mutual funds, pension funds and insurance companies. ${ }^{93}$ Banks began to originate loans specifically to distribute them to nonbank institutions, which came to be referred to collectively as "shadow banks," due to the fact that they provided funding like lenders but were not regulated as banks. ${ }^{94}$ The non-regulated nature of these shadow banks meant that they could avoid the restraints faced by regulated banks, allowing them to make riskier loans. ${ }^{95}$ Thus, regulated banks could avoid

88 Vitaly M. Bord \& João A.C. Santos, The Rise of the Originate-to-Distribute Model and the Role of Banks in Financial Intermediation, 18 FRBNY ECON. PoL'Y REV. 21 (2012). See also Sang Whi Lee \& Donald J. Mullineaux, Monitoring, Financial Distress, and the Structure of Commercial Lending Syndicates, 33 Fin. MGMT. 107, 120-21 (2004).

89 See Bord \& Santos, supra note 88, at 21.

90 Id.

91 See id. at 21-22.

92 See Mayra Rodriguez Valladares, Leveraged Loans and Collateralized Loan Obligations Are Riskier Than Many Want To Admit, ForBES (Sept. 22, 2019), https://www.forbes.com/sites/mayrarodriguezvalladares/2019/09/22/leveraged-loans-and-collateralized-loan-obligationsare-riskier-than-many-want-to-admit/\#2a7cbcf06602 [https://perma.cc/S79Z-DMDS] ("According to today's BIS quarterly review, 'As of June 2019 , over $50 \%$ of the $\$ 1.4$ trillion outstanding leveraged loans in US dollars and about 60\% [] in euros had been securitized through CLOs."'). See also Fin. STABILITY BD., Vulnerabilities, supra note 2, at 3.

93 See Bord \& Santos, supra note 88, at 30 fig.8.

94 See Erik F. Gerding, Law, Bubbles, and Financial Regulation 397-98 (2014) (describing the development of the shadow banking system).

95 See Andrew Berlin, Regulated Banks Soften Stance on Leveraged
Lending
Guidance,
REUTERS
(Apr.
19
2018), 
burdensome regulation but still profit by arranging and selling loans to unregulated entities. The rise of shadow banks also allowed non-bank lenders to compete directly with regulated banks for lending business. ${ }^{96}$ Still, traditional banks continued to lend and retain portions of the loans they extended, usually as a combination of term loans (loans with a stated maturity, usually less than five years) known as Term Loan As ("TLAs"), and revolving credit facilities (loans that can be drawn upon at the discretion of the borrower like a credit card). ${ }^{97}$ Banks ramped up sales to non-bank institutions, preparing tranches specifically for that market. ${ }^{98}$ These tranches, called Term Loan Bs ("TLBs"), usually have longer maturities than TLAs and increasingly looser covenants, making them easier to trade. ${ }^{99}$

As the market for institutional loan facilities grew, banks shifted greater portions of the loans they originated to institutional shadow bank investors. Traditional banks not only originated Term Loan Bs for the express purpose of selling them, but increasingly sold their Term Loan As to non-banks

https://www.reuters.com/article/us-lev-regulation/regulated-banks-softenstance-on-leveraged-lending-guidance-idUSKBN1HQ2XV

[https://perma.cc/VDZ5-NHZQ] (describing how government guidance on leveraged lending caused regulated lenders to step back and allow unregulated lenders to enter the lending market).

96 See id.

97 See William W. Bratton, Bond and Loan Covenants, Theory and Practice, 11 CAP. MKTS. L.J. 461, 482 (2016) ("In the classic picture of corporate bank lending, a term loan follows up on a revolving credit agreement. The revolver has a short-term duration; the borrower draws down funds and repays during the term in accordance with its cash flow requirements. At the end of the term, the borrower has an option to roll the outstanding principal amount over into a five- to seven-year term loan, with the principal and interest payments being meshed onto an amortization schedule."). See also Bord \& Santos, supra note 88, at 30 ("Thus, for credit lines, syndicateparticipant banks . . . tended to hold the credit lines to maturity (or at least for three years). For term loans, in contrast, syndicate-participant banks, like lead banks, have been decreasing the market share they retain at origination and over the years after origination.").

98 See Bratton, supra note 97, at 478-79.

99 See id. These types of institutional tranches are also sometimes labelled Term C, D and so on. See Fin. STABility BD., Vulnerabilities, supra note 2, at 4. For ease of exposition, this Article will refer to all of these collectively as institutional tranches, Term Loan Bs (“TLBs"). 
as well, or stopped issuing TLAs altogether, opting instead to maintain only revolving credit facilities for their client-borrowers. ${ }^{100}$ The net result has been that relationship banks have come to hold an ever-shrinking amount of the debt they originate. ${ }^{101}$ This, in turn, has led to a move away from borrower-lender relationships characterized by familiarity to a market in which non-bank lenders invest in tradeable loans at arms-length, as they might do with bonds or other securities ${ }^{102}$ Although the financial crisis dampened the originateto-distribute market, it gained momentum again rapidly beginning in 2009. ${ }^{103}$ Since that time, not only have traditional banks continued to offload large portions of debt to non-bank lenders, but non-banks have become significant loan originators themselves, creating institutional TLBs for use in their own CLOs and for sale to others. ${ }^{104}$ The evolution in the lending market described here has had important consequences for the incentives and leverage that lenders retain to influence firm behavior, as discussed in the following Section.

\section{Loan Covenants as Levers of Lender Intervention}

Loan contracts contain elaborate sets of covenants that govern the lender-borrower relationship and provide a key point of leverage for creditors to affect company management. ${ }^{105}$ To appreciate how, and to inform the empirical

100 Fin. StABILITy BD., Vulnerabilities, supra note 2, at 5-7 (providing data on the mix of bank versus non-bank loan tranches as of late 2019, and stating that "[o]ver time, the investor base has shifted from a bankdominated paradigm to a more diverse set of investors that also includes a number of non-banks such as institutional investors and finance companies. As a result, the share of Term Loan As and revolvers available on the primary market, which tend to result in bank exposures, has decreased since the financial crisis. In contrast, the share of institutional leveraged loans, typically purchased by non-banks, has increased").

101 See Bord \& Santos, supra note 88, at 25-26.

102 See id.

103 See id. at 29 fig.6, 30-31. See also Fin. Stability BD., VulnerabiliTIES, supra note 2 , at $6-7$.

104 See Sec. Indus. \& Fin. Mkts. Ass'n, supra note 80, at 3-4. See also Fin. Stability BoARD, Vulnerabilities, supra note 2, at 6-7.

105 See Bratton, supra note 97 , at 462. 
analysis below, it is important to understand in more detail the ways in which these covenants operate to influence firms, and how covenants for many loans have departed from past norms. ${ }^{106}$

Historically, covenants in corporate loans served several purposes. Generally, they helped lenders monitor borrowers, alerted lenders if borrowers approached financial distress and ensured that borrowers did not do anything to jeopardize their ability to repay the loan. ${ }^{107}$ Covenants operate to fulfill these functions in several ways. One way is through affirmative promises by the borrower to take certain actions, for example, an agreement by the borrower to provide periodic reports to the lenders to assist in monitoring. ${ }^{108}$ It was this type of covenant that Krispy Kreme initially violated, leading to the removal of its CEO. ${ }^{109}$ Others include promises by a borrower to pay taxes, and generally maintain its business operations as it would be expected to do. ${ }^{110}$

Another class of provisions is negative covenants, which are agreements to refrain from certain actions. ${ }^{111}$ These covenants are usually categorized as business covenants or financial covenants. Business covenants put restrictions on the

106 See, e.g., Joe Rennison \& Colby Smith, Debt Machine: Are Risks Piling Up In Leveraged Loans?, FIN. TIMES (Jan. 21, 2019), https://www.ft.com/content/64c9665e-1814-11e9-9e64-d150b3105d21 [https://perma.cc/GYM8-ULMM] ("So-called financial maintenance covenants - things that would limit the amount of leverage a company could take on, or mandate thresholds for the amount of cash they needed on hand to pay interest on their loans-have close to disappeared. More than 80 percent of the market is now deemed 'cov-lite', according to LCD, meaning financial maintenance protections have been removed.").

107 See Bratton, supra note 97, at 462 (explaining that business covenants "are designed to accord lenders significant influence over the operation of the borrower's business without affecting a transfer of control"); see also Bratton, supra note 29, at 49-62; Robert M. Lloyd, Financial Covenants in Commercial Loan Documentation: Uses and Limitations, 58 TenN. L. REV. 335, 338 (1991).

108 See Bratton, supra note 97, at 463.

109 See supra notes 2-3 and accompanying text. See also Baird \& Rasmussen, supra note 1 , at 1210-11.

110 See Bratton, supra note 97, at 463.

111 See id. 
kinds of activities a borrower can undertake. ${ }^{112}$ For example, common covenants restrict borrowers from incurring new debt beyond agreed limits, undertaking new acquisitions, or giving a security interest in collateral to a new party without the consent of the existing lenders. ${ }^{113}$

Financial covenants create thresholds for borrowers' financial standing, acting both as a deterrent to prevent borrowers from getting into financial trouble and as a warning mechanism to alert lenders if trouble might occur. ${ }^{114}$ Such covenants might include restrictions on spending or limits on changes to the borrowers' mix of assets and liabilities (or income and expenses). ${ }^{115}$ Other common financial covenants include provisions that require borrowers to maintain a minimum net worth (usually defined as assets minus liabilities); a minimum level of cash flow; a minimum leverage ratio (a measure of the money available to service debt, defined as the ratio of total debt to the level of earnings before interest, taxes, depreciation and amortization ("EBITDA")); or a minimum current ratio (defined as current assets over current liabilities-a measure of a borrower's liquid assets available to pay debts). ${ }^{116}$ These tests serve several purposes: they provide a benchmark for a borrower's financial health, help the lender monitor the borrower by providing advance notice if a borrower is in

112 See id. at 465.

113 See id. at 468-75.

114 See id. at 464.

115 See id.

116 See id. at 464 (describing how the tests in typical covenants restrict and control firm spending by "specify[ing] levels of net worth and debt coverage, [and] all ultimately work[ing] toward the same goal-the definition of a permitted degree of leverage. Some of the tests are balance sheet based. A net worth test sets a minimum level of net worth (assets minus liabilities), either as a dollar amount or a ratio. The stated minimum is the smallest equity cushion that the lender must tolerate. Other tests look to earnings or cash flow [implicating income and expenses]. A leverage ratio puts total debt over earnings before interest, taxes, depreciation and amortization (EBITDA) and states a maximum allowed amount with a view to assuring that the borrower's cash flows remain sufficient to service its debt. A coverage ratio puts cash flow over current interest charges (or, alternatively, current interest and principal payments) and states a minimum)"). 
distress, and afford a means for lenders to exert some influence in the borrower's affairs. ${ }^{117}$

\section{The Process of Lender Intervention: Waiver and Renegotiation}

While covenants directly exert influence by imposing duties and restrictions on borrowers, it is when borrowers violate covenants (or come close to violating them) that lenders have the most power. When covenants are breached (for example, by crossing one of the financial thresholds set out in the credit agreement), lenders have the right to declare an event of default and accelerate the loan (i.e., demand immediate payment for all remaining amounts due). ${ }^{118}$ However, lenders rarely exercise this right because doing so would put the borrower into greater financial distress or even bankruptcy, leading the lenders down an uncertain road that may leave them with only a fraction of their investment. ${ }^{119}$ Rather, the value of the acceleration right is often in the leverage it provides to influence the borrowing company. ${ }^{120}$ Lenders exert this

117 See Yong Kyu Gam \& Chunbo Liu, Bank Relationship, Covenant Enforcement, and Creditor Control 9 (Oct. 2019) (unpublished manuscript), https://papers.ssrn.com/sol3/papers.cfm?abstract_id=3486614

[https://perma.cc/6FWN-5MHV] (summarizing existing research and stating that "creditors gain the right to accelerate debt repayment once borrower firms breach covenants (usually financial covenants). Using the threat of payment acceleration, creditors push for significant changes in various firm policies, including but not limited to capital structure, investment and financing decisions, governance and executive compensation. By exerting influence on firm policies, creditor control serves as a tool to enhance corporate governance and increase firm value" (citations omitted)).

118 See id. See also discussion supra Section II.B.2.

119 See generally Tung, Unsung Influence, supra note 1, at 160; Bratton, supra note 29 , at 54 ("The lender may profit little if it takes the occasion of a violation of one of these covenants to exercise its rights in full by declaring an event of default and accelerating the loan. Acceleration as [a] practical matter forces the borrower to make a defensive bankruptcy filing. Bankruptcy entails not only deadweight costs but uncertainties respecting proceeds available for classes of unsecured lenders.").

120 See Tung, Unsung Influence, supra note 1, at 141 (stating that renegotiation of private credit agreements after a violation "is not only common; it is the rule"); Roberts \& Sufi, supra note 12, at 163 (noting that in their sample $96 \%$ of contracts with a stated maturity exceeding three years 
influence in two ways: explicitly through waiving the violation and renegotiating the covenants (frequently resulting in more restrictions on borrowers), and less explicitly through behind the scenes maneuvering. ${ }^{121}$ Behind the scenes maneuvering is often preferable from the lender's perspective because overt actions by the lender can open it to liability from other creditors, or even shareholders. ${ }^{122}$

Thus, covenant violations afford lenders a large amount of influence (and even control) over corporate decisions and policies. ${ }^{123}$ Explicit controls set out in renegotiated covenants work alongside less visible maneuvering that lenders may engage in with borrowers, particularly if those lenders and borrowers have longstanding relationships through repeated interactions over time. ${ }^{124}$ In return for having a covenant violation (or potential violation) waived, borrowers may agree to more stringent loan terms such as a higher interest rate, limits on the amount of debt it may issue, limits on the money it may invest, and restrictions on the dividends it may pay out to its shareholders. ${ }^{125}$ In exchange for a waiver, borrowers may also agree to fire their CEO or other top managers, allow lenders to appoint directors to their board, and even change the direction of company strategy. ${ }^{126}$

had been renegotiated). See also Bratton, supra note 97, at 464 ("Negative covenants indirectly open the door to affirmative lender participation in borrower decision-making by forcing a borrower facing a covenant default to negotiate with the lender for a waiver or amendment.").

121 Lenders often wish to obscure their influence over borrowers to avoid the possibility that they will incur more liability than expected should the borrower experience losses that lead to bankruptcy. See Bratton, supra note 97 , at 462 .

122 See id. at 462 ("When a controlling lender's decisions yield losses, liability to other creditors or even to shareholders can follow."); see also Triantis \& Daniels, supra note 1, at 1097-99.

123 See Tung, Unsung Influence, supra note 1, at 141.

124 See Roberts \& Sufi, supra note 12, at 167.

125 See id. See also Nini et al., Credit Control Rights, supra note 14, at 1713, 1730.

126 See Nini et al., Credit Control Rights, supra note 14, at 1713, 1730 (discussing evidence that top management changes follow covenant violations); Chava, et al., supra note 65, at 481-83 (offering evidence that lender affiliated board members are appointed following covenant violations). 


\section{Changes in the Leveraged Loan Market and the Erosion of Loan Covenants}

The large shifts in the economics of lending over the past decade have led to changes in the kinds of covenants typically seen in syndicated leveraged loans. While these changes have been brought about in part by macroeconomic conditions, the demand for leveraged loans has mostly been spurred by structured finance. ${ }^{127}$ Demand from investors for leveraged loans has risen steadily since 2009, when the economy began to emerge from the credit crisis. ${ }^{128}$ Since then, the issuance of leveraged loans has risen from $\$ 90$ billion in 2009 to $\$ 609$ billion in 2018 , for an estimated total market value of $\$ 1.2$ trillion as of $2019 .{ }^{129}$

The rise in demand for loans has been accompanied by a shift toward more borrower-friendly loan terms, most notably, the move to so-called covenant-light or cov-lite loans. ${ }^{130}$ The

127 See Edison Yu, Measuring Cov-Lite Right, 3 Fed. Res. BanK of Phila. Econ. Insights, Third Quarter 2018, at 1, 2 (noting that "syndicated loans have increasingly been held by institutional investors such as pension funds and mutual funds, either directly or through collateralized loan obligations").

128 Fin. Stability Bd, Vulnerabilities, supra note 2, at 6.

129 See US Leveraged Loan Issuance Downshifts in 2018, with $\$ 609 B$ in Volume, S\&P GLOBAL MKT. InTELligence (Dec. 20, 2018), http://www.leveragedloan.com/us-leveraged-loan-issuance-downshifts-2018-609b-volume/ [https://perma.cc/Q7CF-UVW6]; Fin. STABILITY BD., VulnERABILITIES, supra note 2, at 5. ("Estimates for the size of the global leveraged loan market range from US $\$ 1.4$ trillion to US $\$ 3.2$ trillion as of December 2018, depending on which types of lending are counted."). Note that some estimates report a lower but relatively similar number. See Martin-Buck, supra note 2, at 44 ("The leveraged loan market has grown dramatically over the past 20 years from about $\$ 100$ billion outstanding in 2000 to almost $\$ 1.2$ trillion in 2019.”).

130 See Yu, supra note 127, at 1-2. The shift matches the model set out by Professors Choi and Triantis, who argued that an increased supply of credit would lead to more borrower friendly terms. See Albert Choi \& George Triantis, Market Conditions and Contract Design: Variations in Debt Contracting, 88 N.Y.U. L. REV. 51, 53-56 (2013). Professors Choi and Triantis argue that the shift is driven, at least in part, by a decrease in adverse selection of borrowers, and less moral hazard when macroeconomic conditions are good. See id. at 62-71. This is different, although consistent with the narrative advanced here that the supply of credit and increase in borrower 
most commonly described feature of cov-lite loans is their lack of ongoing financial monitoring covenants. ${ }^{131}$ In such loans, borrower financial health metrics, like leverage ratios and minimum coverage ratios, are not tested continuously as they are in traditional "covenant heavy" loans. ${ }^{132}$ Rather, in cov-lite loans the borrower's compliance with financial ratios is tested only if the borrower undertakes certain transactions, such as issuing new debt or making a major acquisition. ${ }^{133}$ This type of monitoring covenant, known as an "incurrence covenant," is common in high-yield bonds, and leaves the borrower freer to manage its finances as long as it refrains from engaging in a major transaction that causes it to breach its pre-agreed ratios. ${ }^{134}$ However, because the ongoing monitoring function of traditional covenants is missing, the loans do not have the same power to influence borrower behavior on an ongoing basis. In addition, the financial ratios themselves have become more lenient over time, both in terms of their levels and in the ways in which they are calculated. 135 Thus, borrowers are potentially able to get into a precarious financial situation without any advance warning to lenders, and even where lenders do have an advance warning, they may lack the power to influence borrowers' behavior until the borrowers' situation is much worse.

bargaining power are behind the shift. I note, however, that either explanation supports the basic conclusions of this Article.

131 See Meyer C. Dworkin \& Monica Holland, Recent Trends in U.S. Term Loan $B$, in The InTERnAtional Comparative Legal Guide To Lending \& SECURED FinANCE, 26, 26-27 (Thomas Mellor et al. eds., 2d ed. 2014).

132 See id. I note that there a number of other features of cov-lite loans, and that these permutations vary from deal to deal. $I d$. The move to incurrence covenants is commonly cited. See id. at 26.

133 See id. at $27-28$.

134 See id. at 27.

135 One prominent example of this is a more borrower-friendly definition of EBITDA, of which there are many variations. See id. See also Adam B. Badawi \& Elisabeth de Fontenay, Contractual Complexity in Debt Agreements: The Case of EBITDA (Duke Law Sch. Pub. Law \& Legal Theory Series, Working Paper No. 2019-67, 2019), https://papers.ssrn.com/sol3/papers.cfm?abstract_id=3455497 [https://perma.cc/RE6L-U47Q] (identifying previously unexamined variety in the definitions of EBITDA). 
The cov-lite phenomenon was first seen before the financial crisis, beginning around $2005 .{ }^{136}$ The prevalence of these covlite loans faded during the credit crisis, but they began to appear again shortly after. ${ }^{137}$ Between October 2015 and October 2018 , the proportion of leveraged loans that were cov-lite is estimated to have grown from just under $65 \%$ to almost $80 \%$ of the syndicated loan market. ${ }^{138}$ The rising proportion of such loans reflects, in part, the loss of lenders' bargaining power as competition for loans has grown. ${ }^{139}$ It also reflects the changing makeup of term loan investors.

Cov-lite loans are almost always term loans, (most frequently TLBs) held by non-bank institutional lenders. ${ }^{140}$ These investors have historically been active in the market for corporate bonds which, unlike loans, have typically lacked any sort of ongoing monitoring covenants. ${ }^{141}$ Some industry observers have speculated that, in addition to shifts in bargaining power, the move toward cov-lite loans has been facilitated by the fact that non-bank investors are inured to instruments

136 See Yu, supra note 127, at 3-4.

137 See Jerome H. Powell, Member, Bd. of Governors of the Fed. Reserve Sys., Remarks at New York University's Stern School of Business: Financial Institutions, Financial Markets, and Financial Stability 11 (Feb. 18, 2015) (noting that "[p]rice and nonprice terms in the syndicated leveraged loan market have been highly favorable to borrowers . . . The share of loan agreements that lack traditional maintenance covenants increased to historic highs ...." (citation omitted)).

138 See Leveraged Loans: Covenant-Lite Issuance Levels Off, Though Remains Strong, S\&P Global MKT. InTELligence (Nov. 9, 2018), https://www.spglobal.com/marketintelligence/en/news-insights/latestnews-headlines/leveraged-loan-news/leveraged-loans-covenant-lite-issuance-levels-off-though-remains-strong [https://perma.cc/95HU-YYC6].

139 See generally Bo Becker \& Victoria Ivashina, Covenant-Light Contracts and Creditor Coordination, (Sveriges Riksbank Research Paper Series, Working Paper No. 149, 2016), https://ssrn.com/abstract=2871887 [https://perma.cc/MMD2-F6C7] (discussing explanations for the rise of covlite loans, including coordination costs in the lending syndicate and increased borrower demand).

140 See Berlin et al., supra note 24 (manuscript at 2-3).

141 See Becker \& Ivashina, supra note 139, at 2-3. Becker and Ivashina argue that weaker covenants are a rational preference of non-bank institutional creditors. These creditors have incompatible interests regarding the treatment of borrowers who violate covenants, and weakening covenants allows them to avoid conflicts and/or coordination costs. See id. 
with low creditor protection and are therefore less wary of covenant-lite loans. ${ }^{142}$

Moreover, recent research has questioned the extent to which cov-lite loans truly deprive lenders of monitoring and intervention power. One study recently found that all but $15 \%$ of cov-lite loans are made alongside revolving credit facilities that retain full monitoring covenants, and that the revolving facilities are generally retained by a traditional bank lender. ${ }^{143}$ This implies that, for all but $15 \%$ of cov-lite loans, a covenant heavy loan exists and allows a relationship lender to monitor borrowers. Therefore, the absence of covenants may not be the hinderance to lender intervention that it seems, and indeed research (including this Article) shows that covenant violations continue to be reported by borrowers (albeit at lower rates than in the past) despite the increase in covenantlite loans. ${ }^{144}$

But despite the ability to monitor and the continued ability to renegotiate in the wake of covenant violations, it remains questionable whether lenders have the incentive and leverage to exercise the influence that they once did. Even if lenders would otherwise like to renegotiate and force borrowers to comply with their demands, it is possible that they lack the bargaining power to do so when borrowers can easily walk away and find other sources of credit. This is due in large part to the nature of non-bank lenders, particularly structured finance vehicles, that currently hold the majority of leveraged loans. ${ }^{145}$ The reasons for this are further explained below.

142 See id. at 3 ("The bulk of leveraged loans are funded by collateralized loan obligations (CLOs), loan mutual funds, hedge funds, and securities firms, and to a lesser degree, insurance companies and pension funds. Thus, the investor base for leveraged loans today looks much more like the investor base for high-yield bonds. Perhaps it is not that all alarming, then, that the contract between creditors and the borrower in this setting would be cov-lite, as it always has been for bonds.").

143 See Berlin, supra note 24 (manuscript at 35).

144 See id. (manuscript at 13-16).

145 See supra notes $147-50$ and accompanying text. 


\section{Structured Finance and Non-Bank Lenders}

To understand how bank bargaining power and incentives may be changing, it is important also to understand the nature of non-bank lenders and how they affect the lending market. As noted above, demand for loans by non-bank institutional lenders increased dramatically between 2010 and 2019. ${ }^{146}$ This group includes entities such as hedge funds, mutual funds, and insurance companies, with the largest share held by structured finance vehicles known as CLOs. ${ }^{147}$ CLOs are estimated to hold between fifty and sixty percent of all leveraged loans, ${ }^{148}$ driving a large part of the market for them. ${ }^{149}$ By driving this market and providing competitive lending options for borrowers, structured finance is a primary factor driving the increased demand for leveraged loans, and, in turn, the move toward cov-lite and the potential loss of lenders' influence. ${ }^{150}$ Not only do these structures shift bargaining power from lenders to borrowers, they allow lenders to separate ownership and risk, dampening their incentives to monitor in the first place. A description of CLOs and other nonbank lenders helps to explain why these entities might dull lenders' incentives and means to intervene in borrowing companies' governance.

146 See infra note 81 and accompanying text.

147 Martin-Buck, supra note 2, at 45, 46 fig.5, 47. See also Fin. STABILITY BD., VULNERABILITIES, supra note 2, at 2; Yun Lou et al., CLOs' Trading Activity and Performance 3 (Apr. 2014) (unpublished manuscript) (on file with author).

148 Gary Gorton \& Andrew Metrick, Securitization 43 (Nat'l Bureau of Econ. Research, Working Paper No. 18611, 2012); Houman B. Shadab, Credit Risk Transfer Governance: The Good, the Bad, and the Savvy, $42 \mathrm{SE}$ TON HALL L. REV. 1009, 1067 (2012).

149 See Yihui Wang \& Han Xia, Do Lenders Still Monitor When They Can Securitize Loans?, 27 REV. FIn. STUD. 2354, 2358 (2014) (noting that the patterns of issuances in the leveraged loan market pre-crisis track the changes in CLO issuances throughout this time).

150 See Yu, supra note 127 , at 5. 


\section{Collateralized Loan Obligation Function and Form}

CLOs are structured investments based on portfolios of corporate loans. ${ }^{151}$ They are a species of the much-maligned collateralized debt obligations ("CDOs") that are alleged to have contributed to the financial crisis of 2008. ${ }^{152}$ However, CLOs are different because their collateral and payout structure are based on corporate debt, unlike most pre-crisis CDOs, which were based on home mortgage loans. ${ }^{153}$ Like all CDOs, CLOs are structured using a special purpose vehicle ("SPV")a company set up for the sole purpose of holding the loans that make up the core of the investment. ${ }^{154}$ Asset managers acquire a collateral portfolio by buying pieces of syndicated corporate loans. ${ }^{155}$ The collateral in a typical CLO collateral pool can include over one hundred different syndicated loans. ${ }^{156} \mathrm{As}$ of 2018 , an average CLO had a principal balance of $\$ 500-600$ million in outstanding loans, involving an average of 200 corporate borrowers. ${ }^{157}$ The average size of an individual loan in a CLO portfolio was two to three million dollars. 158 The average CLO manager in 2018 controlled 16 CLO vehicles at any one time. ${ }^{159}$

151 Efraim Benmelech et al., Securitization Without Adverse Selection: The Case of CLOs, 106 J. FIn. ECON. 91, 91 (2012).

152 See Wang \& Xia, supra note 149, at 2357-58 (describing CLOs as a type of CDO).

153 See Gorton \& Metrick, supra note 148, at 11-12 (describing the CDO structure and noting the vehicle's underlying collateral consists of asset-backed securities, such as mortgage loans).

154 See id. at 10-11.

155 See Lou et al., supra note 147, at 9.

156 Benmelech et al., supra note 151, at 94.

157 See Zahn Bozanic et al., Corporate Loan Securitization and the Standardization of Financial Covenants, 56 J. ACCT. RES. 45, 46, 51 (2018).

158 Benmelech et al., supra note 151, at 94.

159 See Lou et al., supra note 147, at 4. 


\section{From Risky Loans to Safe Securities: The Alchemy of CLOs}

CLOs bundle leveraged loans-relatively risky loans from debt-laden borrowers-and convert them into "safe" securities. ${ }^{160}$ The loans that go into CLOs are term loans-usually institutional tranches such as TLBs. ${ }^{161}$ Although each of the underlying loans in a CLO portfolio is individually rated, 162 the attraction of the CLO to investors is the tranche structure: interests in the collateral pool are sold as debt instruments issued by the SPV, but these notes carry different risks of loss than the underlying pool of loans. In most such securitizations, the first losses suffered by the collateral pool (for instance, when the first borrowers default) are borne by the lowest tranches of notes (usually called the equity tranches); meanwhile, the highest tranches are the last to lose anything. ${ }^{163}$

Each CLO tranche gets its own credit rating, which is separate than the credit rating of any of the individual underlying loans in the SPV. ${ }^{164}$ The rating of the higher tranches of notes is usually very strong-often AAA, which is the highest rating and essentially the safest form of debt investment. ${ }^{165}$ The higher tranches are rated strongly because loan portfolios are chosen and diversified in a way that minimizes the probability that losses on the entire portfolio will be large enough

160 I note that "safe" is a relative term, commonly employed in the financial services industry to mean that something has a high enough credit rating to be considered relatively risk-free. For an interesting perspective on the vagaries of calling any assets safe, see Anna Gelpern \& Erik Gerding, Inside Safe Assets, 33 YALE J. REG. 363 (2016).

161 Fin. Stability Bd., Vulnerabilities, supra note 2, at 4-6.

162 See Shadab, supra note 148, at 1067.

163 See Gary Gorton \& Andrew Metrick, Securitized Banking and the Run on Repo, 104 J. FIn. ECON. 425, 430-431 (2012) ("[T]he first losses on the pool are allocated to the equity layer at the bottom, with additional losses moving up the capital structure, by seniority, until they reach the AAA tranche at the top.").

164 See id. at 431. ("With each level of securitization, the SPV often combines many lower-rated (BBB, BBB-) tranches into a new vehicle that has mostly AAA and AA-rated tranches, a process that relies on well-behaved default models.").

165 See id. at 430-431. 
to reach the highest tranches. ${ }^{166}$ That safety of the highestrated tranches depends, of course, on the assumptions of the statistical models that predict what, if any, losses are likely to occur on the underlying loans. The financial crisis starkly illustrated how badly things can go if the assumptions of those models do not hold up. ${ }^{167}$

In theory, there are several reasons to believe that CLO managers may have less ability and incentive to intervene in a borrower's affairs than a relationship bank. First, as already explained, CLOs (as well as other non-bank lenders) hold institutional term loans that are increasingly cov-lite, and therefore the loans may not provide a contractual basis for lender monitoring. ${ }^{168}$ Second, even with rights to monitor, loan holders like CLOs often rely on other parties, such as the originating bank or an agent bank, to deal directly with borrowers. Waiving a default may require a vote of the debt holders, or the decision may be delegated to the agent bank. ${ }^{169} \mathrm{In}$ either case, the CLO manager (or any non-bank lender) is relatively removed from the borrower's affairs.

Third, many CLO managers are concerned primarily with the contents of their portfolios and they may lack the personnel or resources to supervise borrowers' businesses on an ongoing basis, even where they have the power to do so. Finally, CLOs hold portfolios of leveraged loans structured such that no single borrower's default would have a large enough impact to materially affect the safety or value of the portfolio as a whole. ${ }^{170}$ This means that, even to the extent that CLO managers have rights to act in the event of a covenant violation, ongoing monitoring and intervention may not be worthwhile or cost effective. ${ }^{171}$ CLO managers can often trade away any loans they think are problematic, and since they seldom have

166 See id.

167 See Gorton \& Metrick, supra note 148, at 56.

168 See supra notes 131-43 and accompanying text.

169 See, e.g., Roberts \& Sufi, supra note 12, at 166.

170 Fin. Stability BD., Vulnerabilities, supra note 2, at 32-33, 33 fig.B1.

171 There is also an argument that institutional investors would prefer to avoid a messy renegotiation process with other non-banks who have incompatible interests. See Becker \& Ivashina, supra note 139, at 2-3. 
an ongoing relationship with borrowing companies, they may find it easier to sell troublesome loans rather than provide help or advice to borrowers. ${ }^{172}$

\section{The Role of Lending Banks and Non-Bank Institutions}

Many of the banks that arrange leveraged loans and sell their participations to CLO vehicles are themselves heavily involved in structuring and underwriting CLOs. ${ }^{173}$ These institutions earn fees in return for underwriting the CLOs and sponsoring their own CLOs, and often retain some portion of the CLO notes. ${ }^{174}$ In so doing these institutions limit their own exposure to some borrowers' creditworthiness, and earn additional profit by creating and investing in CLOs made from loans they arranged or originated. This creates a cycle in which large financial institutions have a greater incentive to lend or arrange loans to sell to CLOs or other non-bank investors. The more CLOs a bank structures, the more it will be incentivized to lend in order to provide collateral for the vehicles it may structure and underwrite later. ${ }^{175}$ Moreover, other types of non-bank institutions such as private equity firms have seized on the demand for loans and begun issuing loans and sponsoring CLOs as well. ${ }^{176}$ Consequently, the issuance volume of CLOs had grown to an all-time high of $\$ 128$ billion for the year of 2018 alone, and an aggregate U.S. volume of

172 Id. at 32. See also Stavros Peristiani \& João A. C. Santos, CLO Trading and Collateral Manager Bank Affiliation, 39 J. Fin. INTERMEDIATION 47, 51-52 (2019) (finding that both bank-affiliated and non-affiliated CLO managers sell off distressed loans, although affiliated managers do so much earlier, due to informational advantages).

173 Fin. Stability BD., Vulnerabilities, supra note 2, at 5.

174 Wang \& Xia, supra note 149 , at 2357.

175 See id. at 2357-58. See also Taylor D. Nadauld \& Michael S. Weisbach, Did Securitization Affect the Cost of Corporate Debt?, 105 J. FIN. ECON. 332, 333, 335 (2012) (finding that large underwriters are likely to sell the loans they arrange to CLO vehicles).

176 See Bord \& Santos, supra note 88, at 30-32 (showing that "traditional institutional investors and, in particular, new loan investors-including investment managers and CLOs-began taking over more of the credit business" in recent years). 
$\$ 656$ billion as of the last quarter of $2019 .{ }^{177}$ In turn, CLOs currently account for two thirds of leveraged loan investment purchases. ${ }^{178}$

\section{Shadow Banks and Changes in Creditor Incentives}

In addition to giving banks incentives to lend by increasing demand, CLOs and other non-bank institutions facilitate banks' ability to lend more. Before the rise of non-banks and the widespread use of structured finance, corporate loans were often held on lenders' balance sheets, leaving them with an incentive to screen and monitor borrowers. ${ }^{179}$ Securitizing the loans-in essence, selling both the right to payment and the risk of default to a CLO_potentially allows lending banks to finance some portion of their loans off of their balance sheets. In other words, securitization allows lending banks to let others take the risk that the borrower will default. ${ }^{180}$ This, as well as loan syndication (i.e., assembling a group of lenders to jointly lend and take the risk of borrower default) has benefits for banks' management of their overall risk, as well as their regulatory capital. For all loans on a bank's balance

177 Kristen Haunss, US CLO Issuance Forecast to Fall in 2020 As Spreads Remain Wide, REUTERS (Nov. 27, 2019), https://www.reuters.com/article/clo-forecast2020/us-clo-issuance-forecast-to-fall-in-2020-asspreads-remain-wide-idUSL1N2870GW [https:/perma.cc/H9YM-CQMG]; Paola Aurisicchio, Wells Fargo Eyeing 20\% Drop in 2020 US CLO Issuance, GLOBAL CAP. (Nov. 26, 2019), https://www.globalcapital.com/article/b1j6d1zfwppdsd/wells-fargo-eyeing-20-drop-in-2020-us-clo-issuance [https://perma.cc/9DLZ-Z6HH].

178 Michael Paladino, Fitch Ratings 2020 OUTloOK: U.S. LeVERAGED FINANCE 3 (2019), https://your.fitch.group/rs/732-CKH-767/images/fitch-ratings-2020-leveraged-credit-outlook-US.pdf [https://perma.cc/GP6S-2XZY] ("[CLOs] represent the largest source of [leveraged loan] demand, purchasing $70 \%$ of new issuance in 2019 by some estimates.").

179 See Benmelech et al., supra note 151, at 95 ("[M] echanisms [for monitoring and screening] include the lead's reputational concerns and the implicit requirement that the lead bank retain a share of the loan on its balance sheet. . . . However, lead banks' incentives to conduct due diligence and monitor borrowers could have become weaker due to broader syndication resulting from large CLO demand.”).

180 See id. 
sheet, the banks must carry a cushion of capital to protect against the possibility that borrowers will default in amounts greater than the bank's expected loan loss reserves. ${ }^{181}$ The more loans a bank makes, the greater the capital it must hold back. ${ }^{182}$ Moreover, banks are restricted by regulatory capital requirements to meet specified ratios in terms of their assets to loan liabilities. ${ }^{183}$ All of this means that as banks lend greater amounts, they face constraints on their ability to make more loans.

However, when a bank syndicates a loan and sells interests to a non-bank, it reduces its potential liabilities and effectively redistributes credit risk to the loan purchasers, giving the originating bank the freedom to make more loans. ${ }^{184}$ The operation thus increases the overall supply of credit in the market by spreading risk to investors. The investors, in turn, buy the loans as part of a structured pool of collateral that, as explained above, has been enhanced to an investment-grade product. ${ }^{185}$

Thus, loan securitization gives loan originators greater flexibility in managing their portfolios by allowing them to lend without greatly expanding the minimum capital they are

181 See Gorton \& Metrick, supra note 163, at 427 ("Bank solvency is promoted by requiring a fraction of deposits to be held in reserve, and in emergencies these reserves can be replenished by borrowing from the central bank.").

182 Id.

183 See Regulatory Capital Rules: Regulatory Capital, Implementation of Basel III, Capital Adequacy, Transition Provisions, Prompt Corrective Action, Standardized Approach for Risk-weighted Assets, Market Discipline and Disclosure Requirements, Advanced Approaches Risk-Based Capital Rule, and Market Risk Capital Rule, 78 Fed. Reg. 62,018, 62,029-082 (Oct. 11, 2013) (to be codified at 12 C.F.R. pts. 208, 217, 225); BASEL COMM. ON BANKIng Supervision, Basel III: A Global Regulatory Framework For More RESILIENT BANKS AND BANKING Systems 12-29 (2011).

184 See Gorton \& Metrick, supra note 163, at 430 ("The bank does not have the resources to keep all of these loans on its balance sheet. In securitized banking the profit comes from the intermediation, not from holding the loans.").

185 Andreas A. Jobst, Collateralized Loan Obligations (CLOs) - A Primer 13 (Ctr. Fin. Studies, Working Paper No. 2002/13, 2002), https://www.researchgate.net/publication/5057386_Collateral-

ized_Loan_Obligations_CLOs_-_A_Primer[https://perma.cc/YY4H-4GH2]. 
required to hold. ${ }^{186}$ It also has the effect of converting illiquid assets (loans) to tradeable debt securities (notes). ${ }^{187}$ Consequently, banks can continue to lend while minimizing the growth of their balance sheets, which in turn increases the availability of credit for corporate borrowers. ${ }^{188}$ This has the added benefit of increasing liquidity in the secondary loan market, as CLO managers and others create a robust market for loans. ${ }^{189}$

\section{Securitization and Governance}

Synthesizing the foregoing discussion of shifting loan market dynamics leads to several possible hypotheses about corporate governance. Generally speaking, the rise in securitization, the competition for lending, and the trend toward an originate-to-distribute model might lead to less lender driven governance, but it is also possible that these changes have had little or no impact.

There may be less creditor governance for both contractual and practical reasons. The increase in cov-lite loans means that both bank and non-bank lenders might have fewer opportunities to intervene, since covenant violations and their waiver and renegotiation are lenders' primary means for doing so. Even where lenders retain mechanisms to intervene, they may lack the incentive to do so for several reasons. First, as bank lenders retain smaller portions of the loans they originate or arrange (and increasingly alienate their interests in loans via securitization and loan trading with non-banks), they may have less reason to engage in monitoring, even though they are in the best position to do so. ${ }^{190}$ This is because monitoring is costly, and as the loan risk they retain

$186 I d$.

187 Id. at 14.

188 Id. at 16.

189 See PALADINO, supra note 178, at 3 (noting that CLOs are the largest drivers of demand for new leveraged loans).

190 See Bord \& Santos, supra note 88, at 22-23 ("[B]anks add value because of their comparative advantage in monitoring borrowers. . . If they instead anticipate keeping only a small portion of a loan ... [t]hey will also have less incentive to monitor borrowers ....”). 
decreases, monitoring and intervention costs may outweigh their benefits. Second, even if banks retain the incentive to intervene, they may find it difficult or impracticable to impose the kinds of demands on borrowers that they once did. In a potential renegotiation, the competitiveness of the market often allows borrowers to readily find other lenders (especially non-banks) willing to lend on less onerous terms than what a bank might want. ${ }^{191}$ Given this reality, banks may be reluctant to intervene too forcefully in the first place, for fear that borrowers will take their business elsewhere. ${ }^{192}$

Third, to the extent that non-bank lenders such as CLOs have the power to affect governance, they may have even less practical ability and incentive to do so. Many of these entities view themselves as investors, not lenders per se, and they often lack the expertise and resources to monitor or intervene. ${ }^{193}$ CLO managers in particular may have even less reason to intervene than other types of non-bank institutions because their compensation is only weakly tied to performance; they receive a base fee, typically senior to that of all notes, simply for managing the loans, regardless of how they perform. ${ }^{194}$ Moreover, although many managers invest in the low-rated equity tranches of their CLOs, their return is still based on diversified portfolios of loans, and they may not find it worthwhile to invest time and effort into any particular borrower. ${ }^{195}$ To the extent that any single borrower's financial distress might make a difference, CLO managers and other non-bank investors can often trade the loan out of their portfolio.

191 Cathy Cunningham, The Cuffs Come Off: The New Decade Brings an Uptick in Cov-Lite Loans, COM. OBSERVER (Jan. 7, 2020), https://commercialobserver.com/2020/01/the-cuffs-come-off-the-new-decade-brings-an-uptick-in-cov-lite-loans/ [https://perma.cc/UX76-3VLC] ("Knowing they're in the driver's seat, borrowers are routinely pushing back on covenants . . ..").

$192 I d$. ("You can be in a very tough position where your borrower is seeing value erode and your hands are tied-you can't do anything about it." (internal quotation marks omitted)).

193 See Bord \& Santos, supra note 88, at 22-23, 28; see also Benmelech et al., supra note 151, at 94-95 (discussing reasons that CLO managers may be less able or willing to monitor borrowers).

194 See Benmelech et al., supra note 151, at 94 (noting the CLO manager compensation is weakly tied to deal performance).

195 See id. 
However, it is also possible that the recent evolution in the lending market has had little or no impact on lender governance. Bank lenders retain full-covenant portions of most the loans they originate, ${ }^{196}$ so it is likely that most of the cov-lite loans held by non-banks have parallel "cov-heavy" tranches, and indeed, recent research has suggested that this is true. ${ }^{197}$ This means that contractual mechanisms still exist to monitor most borrowers and intervene in their affairs, even given the move toward cov-lite. Even where there is no cov-heavy loan and a borrower's terms are entirely cov-lite, incurrence covenants can still be violated. Incurrence covenant violations are more likely to be intentional on the part of the borrower, because the financial ratios are tested upon the occurrence of a transaction instead of on an ongoing basis. ${ }^{198}$ In such cases, borrowers may expect lenders to waive the violation, and may have even arranged it beforehand, but the episode nonetheless would provide an opportunity for lender involvement in firm management. Moreover, even though most TLBs originated in today's market are cov-lite, this change has occurred iteratively over several years; thus it is possible that some nonbank lenders have held (and may still hold) loan interests that retain full covenants. If this is the case, non-bank lenders may have the ability to intervene in the event of a covenant violation for some of the loans they hold.

Bank lenders may find it advantageous to try to impose their preferences on borrowers even if they retain only a small portion of the loan because they are concerned about their reputation, or because they want to establish a long-term relationship with the borrower. Borrowers who similarly value a bank's advice as well as their relationship with the bank may be less inclined to move to a new lender.

It is also possible that the lack of power or incentives for CLOs (and indeed, all non-bank institutional investors) to act in the event of a covenant violation may not be a problem because relationship banks continue to provide this monitoring

196 See Berlin, supra note 24 (manuscript at 35).

197 See Yu, supra note 127, at 3-4.

198 See Dworkin \& Holland, supra note 131, at 27. 
function through their cov-heavy credit facilities. ${ }^{199}$ If this is the case, relationship banks should retain incentives to continue to monitor, and other lenders (like CLOs and other shadow banks) may free ride off the banks' work. ${ }^{200}$

For these reasons, it is not clear ex ante whether the economics of lending, the involvement of non-bank lenders, the rise of securitization, or a combination of these forces affects creditor driven corporate governance. The analysis in Part II below attempts to assess whether this has happened and if so, to what extent.

\section{EMPIRICAL CASE STUDY IN NON- GOVERNANCE: DATA AND ANALYSIS}

This Part discusses the analysis of a large original dataset of corporate loans to assess the extent to which corporate governance intervention by lenders occurs, and how it has changed in the past decade with the changing supply of credit and the rising loan securitization market. I do this by looking at what happens to companies when they violate loan covenants, or have covenant violations waived, because these are the key moments when lenders have power to intervene and when they traditionally have done so. ${ }^{201}$ The empirical analysis consists of three parts. In the first part, I investigate whether the lender governance interventions that were documented in the period before the financial crisis are still apparent in the post crisis period. The goal is to assess whether the changing lending environment has altered banks' intervention patterns over time, irrespective of whether borrowers'

199 See Yu, supra note 127, at 3-4.

200 See id. at 4-5.

201 See, e.g., Nini et al, Creditor Control Rights, supra note 14. I note that for purposes of this analysis, I do not consider whether loans are covlite. If a covenant violation or waiver has occurred, it means either that there is a cov-heavy loan (even if there are also cov lite portions of the loan) or that the borrower has violated (or nearly violated) a covenant in a covlite loan, which is still possible to do. In either case, at that moment lenders have the ability to intervene-cov-lite and cov-heavy borrowers are on equal footing in that respect. Indeed, manual inspection of the covenant violations for which details are reported reveals that generally covenant violations are violations of terms typically found in cov-heavy loans. 
loans are securitized, sold to non-banks or primarily retained by bank lenders. Following the methods used in prior research, I seek to establish whether patterns that held before the financial crisis still hold today.

In this first component of the investigation, I use a firstdifference analysis (an approach that can detect event-driven changes, while still allowing for other changes or trends in each company over time, as per prior studies), ${ }^{202}$ controlling for a number of factors (further described below) that proxy for firm quality and performance, and financial ratios found in loan agreements to which both violators and non-violators are commonly subject. The objective is to see how indicia of firm management change following a violation. If there is a significant and relatively sudden improvement after the violation or waiver, it is an indication that the lenders intervened and that the intervention improved the company's governance and management.

The second part of the analysis examines whether or not there is a divergence between the governance changes of covenant violators whose loans are primarily sold to non-banks or securitized, and those that are primarily retained by banks. If securitizing loans into CLOs or otherwise selling them to other non-banks reduces incentives to monitor, one might expect to see a difference in post-violation outcomes between borrowers in these different groups. I assess whether this is so by breaking the sample of covenant violators and waiver recipients into subsamples reflecting each group, and observing whether or not there is a statistically significant difference in the proxies of lender intervention at the time of the violation or waiver. This portion of the study uses a difference-indifference and triple difference analysis, using pre- and postviolation governance and financial metrics as the first difference, and whether the loans are primarily institutional or securitized (i.e., included in a CLO) as the second and third differences. The technique helps to distinguish statistically significant differences in trends between the two types of loans from differences that are spurious or explained by other confounding factors. I note that I do not attempt to prove a

202 See id. 
causal effect with this analysis; I simply use it to test whether there are statistically significant differences in the outcomes between the groups, and compare these outcomes with what the hypotheses described above might predict.

The third section of the analysis looks at CEO and CFO turnover in the wake of a loan covenant violation. Lenders sometimes exert their influence over borrowers by forcing a change in management, a phenomenon that was documented in the pre-crisis era with respect to loan covenant violations. ${ }^{203}$ If lenders have less bargaining power (or less interest in monitoring), one might expect to see fewer high-level turnovers following a violation. In the analysis below, I investigate whether the lenders continue to force management changes in the wake of covenant violations as they did in the pre-crisis era. I also examine whether the incidence of CEO/CFO turnover with respect to securitized loans varies significantly from the incidence in the case of non-securitized loans.

\section{A. Loan and Covenant Violation Data}

To create the dataset, I start with a sample of firms with quarterly financial data available from the Compustat fundamental quarterly dataset, from July 2008 through June $2019 .{ }^{204}$ I remove any firm-quarter observations for which certain fundamental accounting information is missing; in particular, I remove firm-quarters that have no information for a firm's total assets, total sales, and common shares outstanding at the end of a quarter. ${ }^{205}$ These are dropped because without this information it is difficult to conduct any meaningful analysis with respect to a firm's performance or to compare firms to others for that quarter. Using this preliminary

203 See Nini et al., Creditor Control Rights, supra note 14, at 1715 ("[W]e show that violations are associated with more conservative financial and investment policy and a sharp increase in CEO turnover.").

204 See CRSP/Compustat Merged Database (2008-2019), CTR. FOR RES.

IN SEC. PRICES, LLC, http://www.crsp.org./products/research-products/crspcompustat-merged-database [https://perma.cc/RDZ7-WY55].

205 This method tracks the one used by other researchers with data sourced before the financial crisis. See Nini et al., Creditor Control Rights, supra note 14 , at 1724 . 
dataset, I extract every annual report on Form 10-K and quarterly report on Form 10-Q for each firm from July 2008 through June 2019 from the SEC's EDGAR database. ${ }^{206}$ I match these filings to the initial list of firms taken from Compustat using the SEC's central indexing key ("CIK") where this is available in the database, and the IRS's employer identification number ("EIN") where the CIK is not listed in Compustat. ${ }^{207}$ This results in a dataset of 316,707 SEC filings, each constituting a firm-quarter observation. ${ }^{208}$ Most of the filings are in HTML format, which makes them difficult to read or parse naturally. I therefore use an algorithm to remove all HTML tags (a process commonly referred to as cleaning) in order to render the filings readable and searchable.

Reading over 300,000 filings to find information on loan covenant violations would be a daunting task and therefore, I use a combination of text mining and machine learning techniques to identify the violations and pull out the corresponding data. First, I search the "cleaned" SEC filings for information about loan covenant violations. Such violations must be disclosed pursuant to Regulation S-X, even if they have been waived by the lender. ${ }^{209}$ In addition, SEC guidance states

206 See Electronic Data Gathering, Analysis, and Retrieval ("EDGAR”) Company Filings Database (2008-2019), SEC. \& Exchange Commission, https://www.sec.gov/edgar/searchedgar/companysearch.html

[https://perma.cc/Z54G-KNLL]. Data from 2019 was gathered even though violations were only collected through 2018 in order to measure financial outcomes that lag the 2018 violations.

207 Abbreviations in parentheses denote the Compustat codes for these accounting items.

208 See Electronic Data Gathering, Analysis, and Retrieval ("EDGAR") Company Filings Database, supra note 206.

209 See 17 C.F.R. § 210.4-08 (2019) (requiring that "[t]he facts and amounts concerning any default in principal, interest, sinking fund, or redemption provisions with respect to any issue of securities or credit agreements, or any breach of covenant of a related indenture or agreement, which default or breach existed at the date of the most recent balance sheet being filed and which has not been subsequently cured, shall be stated in the notes to the financial statements. If a default or breach exists but acceleration of the obligation has been waived for a stated period of time beyond the date of the most recent balance sheet being filed, [the issuer must] state the amount of the obligation and the period of the waiver"). The SEC has also stated that companies should disclose if they are reasonably likely to breach 
that firms must disclose if they are reasonably likely to breach a covenant. ${ }^{210}$ The search algorithm identified any mention of the word "covenant" or "covenants" within five lines (thirty characters) of the words "waiv," "viol," "in default," "modif," or "not in compliance." ${ }^{11}$ A manually searched sample of 1,000 filings reveals that the search algorithm is vastly over-inclusive, identifying approximately eight false positives for every one true violation in the data, but that the majority $(97 \%)$ of violations are captured in the search.

In order to separate the true positives from false positives, I manually coded 1,000 of the filings and used a machine learning algorithm to separate true positives from false positives. ${ }^{212}$ In order to do this, I used 600 of the 1,000 hand-coded filings to iteratively train a deep neural net to classify the remaining filings. ${ }^{213}$ This process is an iterative one. Each time the algorithm is trained, it is tested against a sample of 200 documents held out. Any mistakes are then corrected and become inputs into the next iteration to train the neural net. By

a loan covenant. See Commission Guidance Regarding Management's Discussion and Analysis of Financial Condition and Results of Operations, Securities Act Release No. 33-8350, Exchange Act Release No. 34-48960, 68 Fed. Reg. 75,056, 75,064 (Dec. 29, 2003) (to be codified at C.F.R. pts. 211, 231, 241).

210 See Commission Guidance Regarding Management's Discussion and Analysis of Financial Condition and Results of Operations, 68 Fed. Reg. at 75,064 .

211 This method is similar to that used in prior research on lender interventions. See Nini et al., Creditor Control Rights, supra note 14, at 1724.

212 A detailed explanation of my research method is curtailed to limit the length and highlight the main point of the Article.

213 This method has begun to see wider use in legal research and practice. See, e.g., Gabriel Rauterberg \& Eric Talley, Contracting Out of the Fiduciary Duty of Loyalty: An Empirical Analysis of Corporate Opportunity Waivers, 117 CoLUM. L. REV. 1075, 1121-40 (2017) (using a machine learning classifier to identify fiduciary duty waivers in SEC filings). The method is already widely used by law firms to sift large troves of documents in discovery. See Lauri Donahue, A Primer on Using Artificial Intelligence in the Legal Profession, JolT DigEsT (Jan. 3, 2018), https://jolt.law.harvard.edu/digest/a-primer-on-using-artificial-intelligence-in-the-legal-profession [https://perma.cc/ME7Y-2S97]. 
the end, the neural net had 99\% accuracy classifying documents in the test sample. ${ }^{214}$

After the classifier was run on the remaining data, I performed a further check on 200 randomly selected filings to test for accurate classification. I found that the classifier had correctly identified each one. The result was a sample of 3,581 firm-quarters for which a new covenant violation was reported, involving 1,446 borrowing companies. The entire dataset was then matched with the long-term bond rating data from Standard \& Poor's for each company in each quarter. ${ }^{215}$

The first noteworthy finding from the data concerns the basic trend in covenant violations over time. The trend over time with respect to covenant violations reported in $10-\mathrm{Ks}$ and 10 -Qs is illustrated in Figures 1 and 2 below. Figure 1 shows the total number of violations reported between 2008 and 2018. Figure 2 shows the "new" covenant violations. Since companies report the same violation during the entire time it is ongoing, I isolate violations which are reported for the first time, i.e., for companies that have no violations reported for the preceding four quarters.

214 The machine learning classifier even picked up mistakes that I had made in hand-coding the filings.

215 Since the data is taken from publicly filed documents, the sample necessarily omits leveraged buyout borrowers and borrowers who were otherwise taken private after the loan was made. This is because the empirical analysis requires an assessment of financial metrics for a period of time following a covenant violation or waiver, and this information is not available for most companies that have gone private. This also means that the analysis will not necessarily bear on private equity firms, a major type of leveraged loan borrower and lender. Nonetheless, the dataset provides a rich cross-section of public borrowers that comprise a significant portion of the lending market. 
Figure 1: Total Covenant Violations Reported from 2008-2018 216

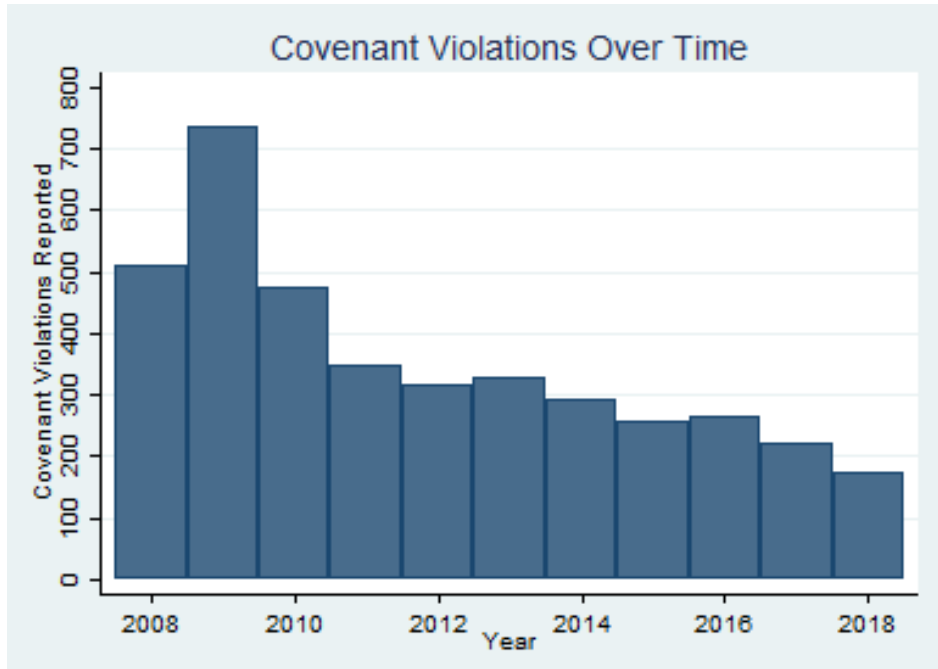

216 This figure summarizes information included in the data set created by the author. See Jeremy McClane, Covenant Violation Data Set (on file with the Columbia Business Law Review). The Covenant Violation Data Set Appendix is also available at https://papers.ssrn.com/sol3/papers.cfm?abstract_id=3628810 [https://perma.cc/VCG6-LP8N]. 


\section{Figure 2: New Covenant Violations Reported from 2008-2018 217}

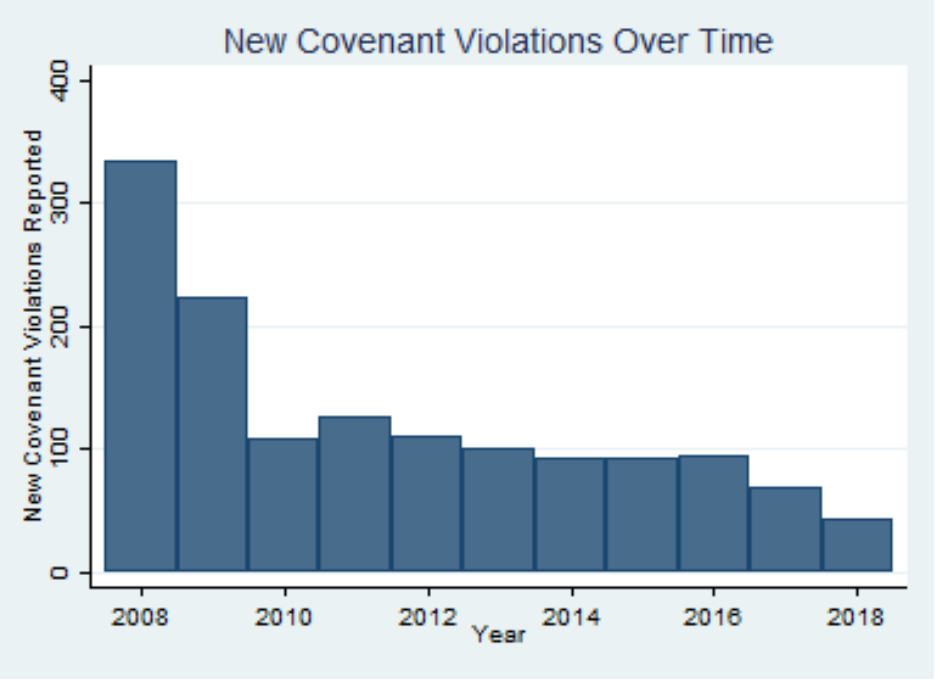

Evident from Figures 1 and 2 is that a large number of violations were reported in the first few years of the dataset (not altogether surprising given the financial distress that was occurring at the time) but that the number of violations has declined steadily since then. In particular, the number of violations dropped off in 2017 and 2018. The pattern is consistent with a relatively good economic environment for borrowing firms, as well as an increase in cov-lite loans, which provide fewer avenues for a covenant violation. ${ }^{218}$

217 This figure summarizes information included in the data set created by the author. See id.

218 Cunningham, supra note 191. The nature of the violation (or near violation) is reported for many, but not all, of the violating companies. Manual inspection of the SEC filings reveals that reported violations for which details were given primarily involved breaches (or near breaches) of financial covenants involving common ratios and financial metrics. For example, a typical covenant violation disclosure looks like the following:

During the second quarter of 2010 the Company was not in compliance with an earnings-related covenant and a minimum tangible net worth covenant in its Credit Agreement. The Company is in the process of obtaining appropriate 
Observations were matched with data from the Refinitiv Loan Pricing Corporation DealScan database, a database of loan transactions and deal information. ${ }^{219}$ The DealScan database contains only a portion of the loans and other debt instruments involving public companies at a given time, and thus does not include all of the loans taken by companies in the initial dataset, or all of the companies that reported covenant violations in the time period studied. ${ }^{220}$ Nonetheless, the initial dataset was successfully matched with 10,105 debt transactions involving 3,370 companies, 1,416 of which were covenant violators.

For the second part of the analysis (the analysis of CEO and CFO departures), I extracted information from Forms 10$\mathrm{K}, 10-\mathrm{Q}$ and $8-\mathrm{K}$ regarding turnover of senior company officers. As previously mentioned, lenders sometimes exert their influence by forcing a change in management, a phenomenon that was documented in the pre-crisis era with respect to loan covenant violations. ${ }^{221}$ Although it is not possible to directly observe whether a lender influences a senior officer to step down from their role (and indeed, lenders have reason to keep their influence over such processes obscure), ${ }^{222}$ when a departure occurs suddenly after a new loan covenant violation occurs, a plausible inference is that the lender had some influence over the process. ${ }^{223}$ The inference becomes even more

waivers for the covenant violations and has recently completed discussions with its lender, and a new credit agreement is being drafted and is anticipated to be executed with the agreed upon terms and conditions.

Supreme Indus., Inc., Quarterly Report (Form 10-Q), at 7 (Aug. 10, 2010).

219 See DealScan Database (2008-2019), Refinitiv LOAN PRICING CORP., https://www.refinitiv.com/en/financial-data/market-data/lpc-loanpricing/loanconnector-loan-information-platform [https://perma.cc/TZ4S$\mathrm{X} 2 \mathrm{CL}]$.

220 Id.

221 See Nini et al., Creditor Control Rights, supra note 14, at 1741-46; see also Baird \& Rasmussen, supra note 1, at 1211.

222 See Bratton, supra note 97, at 462 (noting that lenders prefer to work behind the scenes to avoid liability to other creditors and shareholders).

223 CEO departures in the quarter immediately following a covenant violation has been measured in prior financial economic research on lender 
plausible if there is a systematic pattern of such departures after new violations for different companies. Part of the analysis below investigates whether or not this pattern persists with respect to debt that is originated for non-banks or debt that is primarily securitized in CLO vehicles, and whether the pattern changes as the market for credit becomes more competitive. The analysis and results that come from this data are further described below.

\section{B. Financial Proxies for Lender Intervention}

Since lender intervention cannot be observed directly, research on debt governance uses a number of accounting-related proxies to assess whether lenders have influenced a borrower following a covenant violation. These accounting measures are indicators for a firm's financial health and the quality of management. Prior research has shown that these metrics tend to deteriorate in the period leading up to a covenant violation, but they improve significantly in the four quarters following a violation in response to the waiver and renegotiation process with lenders. ${ }^{224}$

Three categories of performance indicators are particularly relevant to lenders and offer important insights. These are: financial conservatism, investment conservatism, and operating performance. In essence, these three measures gauge the extent to which borrowers cut back on acquisitions, reduce borrowing, and improve their costs and cashflow following a covenant violation. Such changes speak to lenders' monitoring and influence vis-à-vis borrowers. If companies exhibit financially irresponsible behavior before the violation, and then markedly improved financial responsibility following the violation, it is compelling evidence that the lender intervened either directly or indirectly. These measures and their importance are explained below.

interventions. See, e.g., Nini et al, Creditor Control Rights, supra note 14, at $1741-46$.

224 See id. at 1726-32, 1757. 


\section{Financial Conservatism}

The first category of performance indicators proxy for $f i$ nancial conservatism, i.e., how careful a company's management is in conserving the company's funds and limiting debt issuances in the periods before and after a violation. Accounting measures that proxy for financial conservatism are: the change in total cashflow of the firm (as a percentage of the total assets), the change in the amount of shareholder payouts made (i.e., how much the company's money is being poured into share buybacks or dividend distributions), the change in the total debt of the company (scaled by the amount of the company's assets, so that the metric can be compared across firms of different sizes), and the change in the company's net debt issuance, or, how much new debt a company takes on without eliminating old debt. ${ }^{225}$

Of particular interest are the shareholder payout metrics and debt-related measures. Each of these are the subject of common loan covenants, the goal of which is to constrain the agency costs of debt, i.e., to prevent managers from taking action to benefit themselves or shareholders that might put their ability to repay the loan at risk. ${ }^{226}$ In addition to restricting new debt issuances, covenants sometimes limit shareholder payouts to prevent the transfer of assets to shareholders at the expense of creditors. ${ }^{227}$ Given that, it should come

225 These categories are used in other studies of lender interventions and firm management. See, e.g., Nini, et al., Creditor Control Rights, supra note 14, at 1737. Other scholars have used metrics such as Tobin's Q to measure management effectiveness. See, e.g., Shepherd et al., What Else Matters, supra note 1. Tobin's Q attempts to measure the replacement cost of the intangible assets of a firm, one of which is assumed to be management's ability to run the firm well. See id. Although it has been widely used in research on the value of corporate governance provisions, its effectiveness has been called into question as an adequate measure of the value of firm governance. See, e.g., Robert Bartlett \& Frank Partnoy, The Misuse of Tobin's Q, 73 VAND. L. REV. 353 (2020). The measures used here are more nuanced and diverse than Tobin's Q. All of them, taken together, provide a robust means of measuring management's performance on specific criteria.

226 See Bratton, supra note 97, at 466-74.

227 See Bratton, supra note 29, at 50-51; Nini et al., Creditor Control Rights, supra note 14 , at $1737-38$. 
as no surprise that violations often occur in tandem with, and sometimes as a result of, an increase in new debt issuances or shareholder payouts, and that lender intervention results in bringing the level of these metrics back down. ${ }^{228}$ Regardless of whether restrictions on such payouts cause or are caused by violations, a rise in shareholder payouts indicates less financial conservatism and greater agency costs with respect to lenders (although not necessarily with respect to shareholders). In addition, large shareholder payouts may arguably be bad for a firm's long-term prospects if they divert money away from useful projects, research and development, or providing a cushion in the event of future financial problems. Similarly, total debt and net debt issuances might be restricted by covenants, and restrictions on new debt issuances might be imposed as part of a waiver agreement or loan renegotiation. ${ }^{229}$ In any event, changes in these measures are good indicators of lender intervention.

\section{Investment Conservatism}

The second category of performance metric is investment conservatism. Investment conservatism is related to financial conservatism, in that it measures how carefully management uses its resources, but investment conservatism focuses specifically on how much of a company's resources are being put toward major acquisitions. ${ }^{230}$ Acquisitions are often limited by standard loan covenants. ${ }^{231}$ Even cov-lite loans often contain restrictions on acquisitions, often in the form of financial ratios that are tested at the time an acquisition is made. ${ }^{232} \mathrm{Ma}-$ jor acquisitions can, of course, have positive results for a company; however if a company is in distress to the point that it is violating covenants in its loan agreements, lenders often prefer that companies be conservative with such acquisitions,

228 See Nini et al., Creditor Control Rights, supra note 14, at 1735-37.

229 See Bratton, supra note 29, at 49-50.

230 See id.

231 See Bratton, supra note 97, at 473-75; Nini et al., Creditor Control Rights, supra note 14 , at 1737.

232 See Dworkin \& Holland, supra note 131, at 26. 
and not spend money that could otherwise be used to pay the loan or ensure the firm is on solid financial footing. ${ }^{233}$

Investment conservatism is typically measured by looking at a number of accounting metrics: changes in a company's assets (in log scale to normalize the distribution of changes in assets and allow for comparability), the change in a firm's property, plant and equipment balance sheet item-an accounting measure of a company's major capital assets and another way of assessing a company's large investments-(in log scale for comparability), the change in a company's capital expenditures, which measures its outflow of capital to acquire significant new property (scaled by assets, again, for comparability), and changes in cash acquisitions, a measure of the outflow of a company's cash spent on major purchases (also scaled by assets). ${ }^{234}$

As with financial conservatism, measures of investment conservatism are directly affected by covenants commonly found in loans. ${ }^{235}$ Covenants might directly limit mergers or sales of assets. ${ }^{236}$ They might also limit capital expenditures (expenditures for fixed or capital assets). ${ }^{237}$ Acquisitions may trigger an incurrence covenant in a cov-lite loan, giving the lender cause to check a borrower's financial ratios and declare a covenant violation if the acquisition has caused the ratios to be exceeded. ${ }^{238}$ Capital expenditures are often necessary to maintain a business, but lenders might impose a cap to ensure that money is invested in more liquid assets and is thus readily available to pay debt. ${ }^{239}$ Acquisitions might similarly be limited to conserve cash for debt repayment and deter the

233 See Nini et al., Creditor Control Rights, supra note 14, at 1737 (noting that "corporate credit agreements often contain an explicit restriction on capital expenditures and acquisitions, which provides a contractual mechanism for creditors to limit investment following a covenant violation").

234 See id. at 1736.

235 See Bratton, supra note 97, at 473-75. See also Nini et al., Creditor Control Rights, supra note 14, at 1737.

236 See Bratton, supra note 29 , at 52-53.

237 Id. at 53.

238 See Dworkin \& Holland, supra note 131, at 27-28.

239 Id. 
purchase of risky assets at the expense of safer ones. ${ }^{240}$ In any event, where these measures decline prior to a covenant violation and improve thereafter (from the perspective of lenders at least), lender influence can be inferred.

\section{Operating Performance}

The last category is operating performance. Operating performance can be measured in accounting terms as: changes in operating cash flow (scaled by the amount of assets a firm has to maintain comparability with other firms), the change in revenues from sales, and the change in operating costs (the latter two are both transformed to their natural log, in order to mitigate skew and make the distributions comparable between periods and between companies). ${ }^{241}$ Finally, the market-to-book ratio of the firm is also sometimes used as a performance metric. This ratio measures the relationship between the market price of a firm's shares and the value of the firm's assets as recorded in historical terms on its balance sheet. ${ }^{242}$ The metric is intended to proxy for the additional value (or replacement cost) that shareholders attribute to the firm's intangible assets and growth potential, and thus has been used as a rough signal for the effectiveness of the firm's management. ${ }^{243}$

\section{General Approach and Controls}

The average effect of a covenant violation on the proxies just described is assessed below. When covenants are violated, lenders often agree to waive the transgression. Historically, waivers were given in exchange for the borrower's agreement to take actions to run the company in a way that is less financially risky. ${ }^{244}$ If this still occurs and these measures are

$240 I d$. at 52-53.

241 See Nini et al., Creditor Control Rights, supra note 14, at 1747-49.

242 See Shepherd et al., What Else Matters?, supra note 1 (using Tobin's $\mathrm{Q}$ as a measure of firm value, calculated as the ratio of a firm's market value to book value).

243 See Bartlett \& Partnoy, supra note 225, at 373-74 (noting the use of market-to-book ratio in many studies).

244 See Tung, Unsung Influence, supra note 1, at 151-52. 
effective, it should be apparent in the data as changes in the performance metrics described above, occurring shortly after a new covenant violation.

Data for the entire pool of covenant violators reveals evidence that, on average, lender intervention occurs. For most of the financial metrics described above, companies' average performance deteriorates until the quarter of the violation, but the measures improve significantly by the fourth quarter after the violation. This suggests that lenders have continued to respond to covenant violations in ways that have helped companies improve their operating performance, and practice more financial and investment conservatism. In doing so, it is plausible that these creditors also reduced agency costs by reducing managerial slack. The graphs in Figure 4 illustrate these trends in the raw data, and the trends are analyzed statistically as described further below.

This analysis looks at initial covenant violations only. Since violations are sometimes ongoing for multiple quarters, using each violation would effectively double count some violations. To mitigate this problem, I assume that new violations are those reported after at least four quarters (one year) during which no violation is reported. I assume that violations reported in successive quarters, or violation reports separated by less than one year are the same violation.

The trends evident in the raw data are supported using a first difference approach. A first difference analysis allows for the measurement of how a firm's performance changes over time, using various controls, in comparison with other firms, and has the additional advantage of negating the effect of time-varying, firm-specific characteristics that might otherwise lead to biased results. In other words, the approach accounts for changes that companies might experience over time that are not specific to violating loan covenants, but that might otherwise affect the results. ${ }^{245}$

The analysis uses a number of controls to account for other possible determinants of firms' performance. ${ }^{246}$ Fixed effects

245 The results of these analyses are reported in tables created by the author. See McClane, supra note 216.

246 See id. 
are included for each borrower's industry (as two-digit standard industry classification codes) and for each calendar quarter. Controls are used for the long-term bond rating of each company and for several measures that proxy for firm size and quality commonly used in the financial economic literature: firm assets (as the log of total assets), firm age, return on assets, the leverage ratio, the ratio of interest expense to average assets, the ratio of net worth to total assets and the current ratio. ${ }^{247}$ The ratios are the subject of ubiquitous financial covenants in loan agreements ${ }^{248}$ included to control for differences between firms and their loans. ${ }^{249}$

247 These are further explained in the appendix to the covenant violation data set. See McClane, supra note 216, at tbls. 2-7. These controls are consistent with those used in other research studies on the impact of covenant violations. See, e.g., Nini et al., Creditor Control Rights, supra note 14, at 1731 tbl.9. In addition, the number of lenders in a syndicate have been found to influence the aggressiveness with which lenders respond to covenant violations. See Sudheer Chava \& Michael R. Roberts, How Does Financing Impact Investment? The Role of Debt Covenants, 63 J. Fin. 2085, 2087, 2112-13 (2008) (discussing the aggressive response of solo lenders as compared to those in a large lending syndicate). This is thought to occur because smaller lenders in a smaller syndicate each face more risks, and potentially have fewer mechanisms for reducing information asymmetry between themselves and the borrowers. See Tung, Unsung Influence, supra note 1 , at 156 n.198, 163-64. Smaller lending groups may also find it easier to renegotiate loan terms than larger syndicates, which face coordination problems. See Patrick Bolton \& David S. Scharfstein, Optimal Debt Structure and the Number of Creditors, 104 J. PoL. ECON. 1, 3 (1996). The vast majority of the loans in the sample studied here involve syndicates of five lenders or more, thus mitigating the concern that single lenders or small syndicates might affect the results. In unreported regressions, I include a control for the number of lenders, and the results remain consistent.

248 See Bratton, supra note 97, at 464.

249 See, e.g., Nini et al., Creditor Control Rights, supra note 14. 
Figure 3: Measures of Operating Performance Before and After Loan Covenant Violation ${ }^{250}$
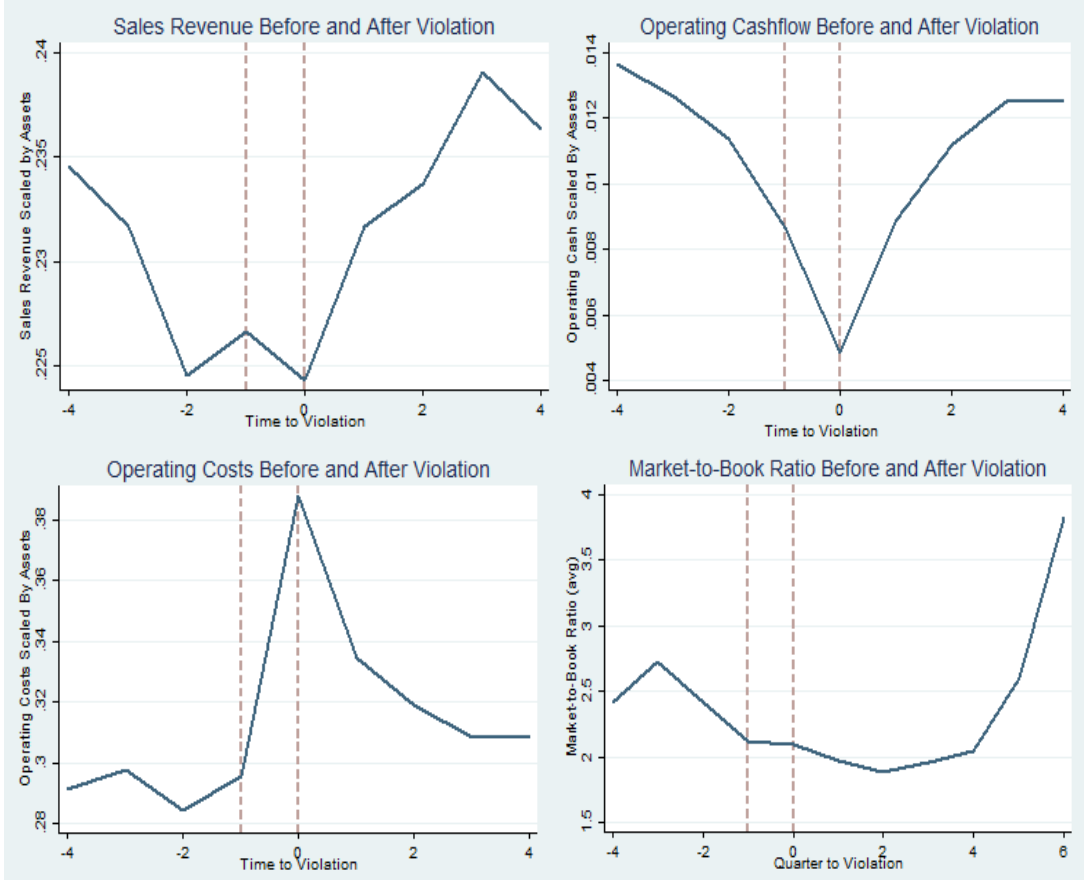

250 This figure summarizes information included in the data set created by the author. See McClane, supra note 216. 


\section{Figure 4: Measures of Financial Conservatism Before and After Loan Covenant Violation ${ }^{251}$}
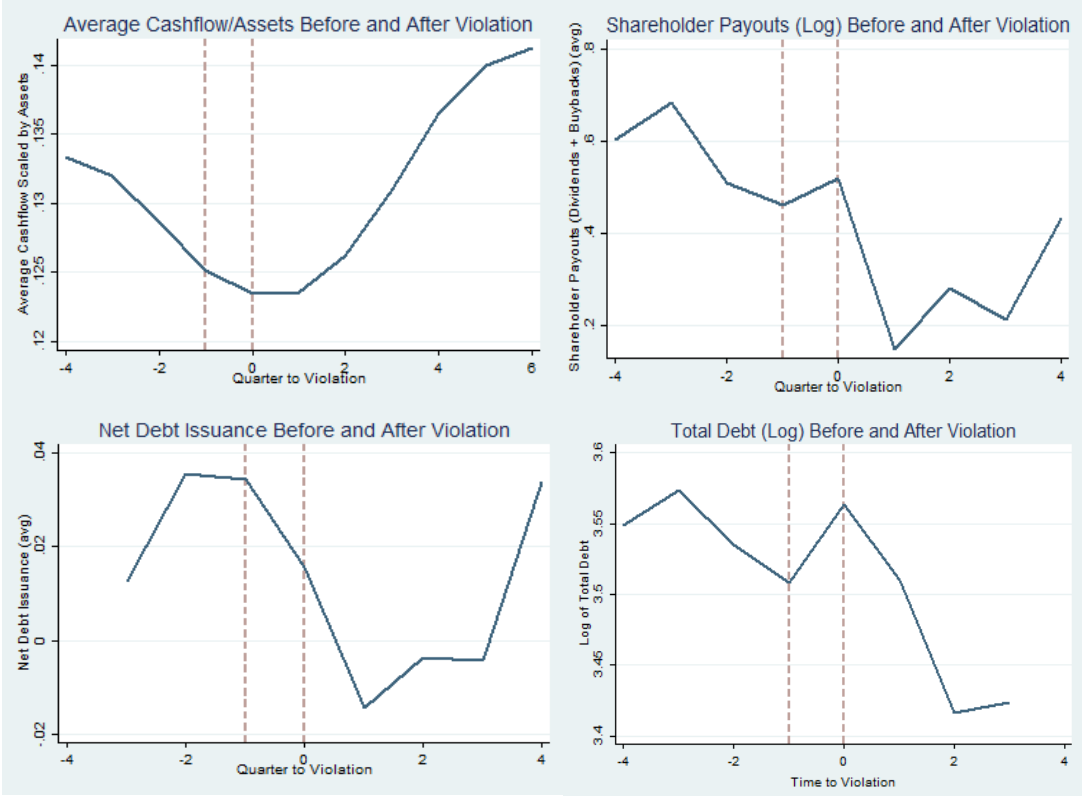

\section{Lender Intervention: Institutional Loans and CLO Loans}

The analysis above provides evidence that, on average, lenders continue to intervene when borrowers violate covenants or obtain waivers. These pooled results do not account for differences among borrowers whose loans are sold to nonbanks or securitized. It is possible that differences in outcomes with respect to such loans are masked by the averages of the entire pool. To assess whether borrowers with primarily institutional or securitized loans experience differences in outcomes, I create subsamples of each and analyze what happens leading up to and following a violation or waiver. I look at the raw data and use a difference-in-difference analysis to assess whether the proxies for lender interventions are statistically

251 This figure summarizes information included in the data set created by the author. See McClane, supra note 216. 
significantly different from the overall averages when a borrower's loans are primarily institutional loans, and when they are bundled into CLOs, as opposed to when they are not. To do this, I first identify institutional loans and loans that are put into CLOs, using a subset of the data for which DealScan information is available. DealScan provides the identity of the lenders in the lending syndicate, the arranger, and the type of loan, among other information. ${ }^{252}$ Most of the loans are one of two types: term loans (i.e., loans made for a set period of time) and revolving credit facilities (lines of credit that borrowers can draw upon at any time). Two realities of the non-bank institutional and CLO market allow me to identify the loans held by non-banks, as well as the loans that are securitized. First, institutional term loans (i.e., TLBs) are created for the institutional market, with an eye toward their sale to nonbank lenders. ${ }^{253}$ They can be contrasted with a TLAs or revolving credit facilities, for which the initial arranger usually remains the lender and retains its relationship with the borrower. ${ }^{254}$ Therefore, any loan or loan tranche with a TLB designation can be categorized as held by non-bank lenders.

Second, when a syndicate includes CLO special purpose vehicles, the loans will invariably be securitized. ${ }^{255}$ In addition to the loans that are originated with the securitization vehicle in the syndicate, it is possible that loans originated by a syndicate without an SPV can later be acquired by such a vehicle, for example, when an underwriter warehouses the loans for later use in a CLO. ${ }^{256}$ To identify these loans, I use data curated by Creditflux, a data provider that tracks CLOs and loan trading. ${ }^{257}$ The database, titled CLO-i, contains each trustee report for a large set of CLOs from 2008 through 2019; the trustee reports in turn provide information on the

252 See DealScan Database, supra note 219.

253 See Wang \& Xia, supra note 149, at 2359; see also FIn. STABILITY

BD., VulneRABILITIES, supra note 2, at 4-5

254 Fin. STABILITY BD., Vulnerabilities, supra note 2, at 4-5.

255 See supra notes 125-31 and accompanying text. See also Benmelech et al., supra note 151, at 94-97.

256 See Benmelech et al., supra note 151, at 96-97.

257 See CLO-i (2008-2018), CREDITFLUX, https://cloi.creditflux.com [https://perma.cc/4C5G-E5WF]. 
holdings of each CLO for each reporting period, including the names of borrowers and the principal amount held of each borrower's loan. ${ }^{258}$

Using this data, I identify a sample of borrowers whose loans are primarily held by non-bank lenders, and a further subsample of borrowers whose loans are held by CLOs. In the institutional loan sample, I include any borrower a majority of whose loans are held by non-banks. I define this group as borrowers for whom greater than $50 \%$ of their leveraged loans are held by non-bank institutions.

Of this group, I create a further subsample of borrowers whose loans are securitized. I include a borrower in this group if any portion of their loans are determined to be held in a CLO, using the method described above. I do not use a threshold cutoff for this subsample; the average principal balance of these borrowers' loans held by CLOs is $76 \%$, with a median of $23 \%$ in a given quarter. As a robustness check, I also do an alternative analysis to test the results of the primary one. In the alternative specification, I identify the market share of each lead loan arranger in the CLO market. ${ }^{259}$ I obtain information on market shares from Asset-Backed Alert, a provider of data on asset backed securities. ${ }^{260}$ The market share of these arrangers changes enormously over the time period covered by the data, with a number of arrangers heavily entering the CLO market between 2008 and 2019.261 I use the arranger's relative position among CLO underwriters and managers to proxy for the likelihood that the debt was used in a CLO. If the lead arranger was in the top ten CLO underwriters for the fiscal quarter in which a loan package was given, or one quarter before or after, I assume that the loan was included in a CLO.

It is possible, of course, that this dataset omits some CLOs and their managers, and therefore miscategorizes some

258 See id.

259 This method is similar to that used by Wang \& Xia. See Wang \& Xia, supra note 149, at 2360-64.

260 See CLO Market Makers, AsseT-BACKed AleRT (May 17, 2019), https://www.abalert.com/documents/FG/hsp/rankings/597521_CLOMarketMakers.pdf [https://perma.cc/5ZK3-DGNA].

261 Id. 
borrowers. For example, if a CLO manager that is not part of a lending syndicate acquires loans after they are originated, ${ }^{262}$ and is also not included in CLO-i for some reason, then the universe of loans that should be included in the CLO subsample may be larger than the sample I collected. However, given the comprehensiveness of the CLO-i database, the number of such borrowers is likely to be small. Moreover, even if borrowers are erroneously omitted from the CLO category my sample represents a lower bound on CLO loans. However, given the realities of the CLO market discussed in the preceding Section, it is extremely unlikely that loans purchased by CLO managers after origination would be treated differently than loans originated for the purpose of distribution and securitization. ${ }^{263}$ Thus, any statistically significant results may underestimate the true difference between securitized and nonsecuritized loan borrowers; but such estimates nonetheless represent an important finding regarding the presence or absence of lender intervention.

\section{Basic Results: Raw Data}

Even without any sophisticated analysis, some patterns are visible in the raw data. While there are no obvious differences between the institutional sample and the larger sample, there are notable differences between borrowers in the CLO subsample and all other borrowers. For illustrative purposes, Figure 5 below shows the pattern with respect to some of the outcome variables described above.

These graphs show changes in metrics of financial conservatism, investment conservatism, and operating performance in the four quarters leading up to a covenant violation and waiver, and the four to six quarters afterward. The solid line represents borrowers whose loans are not placed into CLOs while the dashed line represents borrowers whose loans are included in CLOs. The vertical lines represent the quarter during which the violation and waiver took place. 33.

262 See Fin. Stability BD., Vulnerabilities, supra note 2, at 4-5, 32263 See supra Sections II.B-C. 
The figures show the medians in the raw data. To confirm the statistical significance of these differential outcomes, I use a difference-in-difference analysis. ${ }^{264}$

Figure 5: Performance of CLO Versus Non-CLO Loans Before and After Covenant Violations ${ }^{265}$

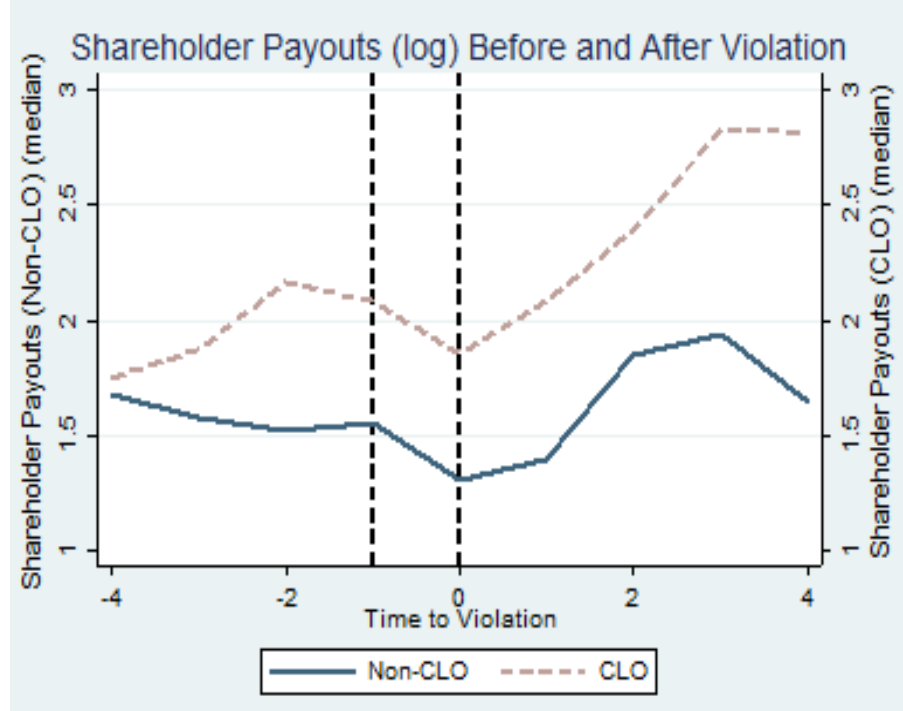

264 See McClane, supra note 216, at tbls. 9-11.

265 This figure summarizes information included in the data set created by the author. See McClane, supra note 216. 

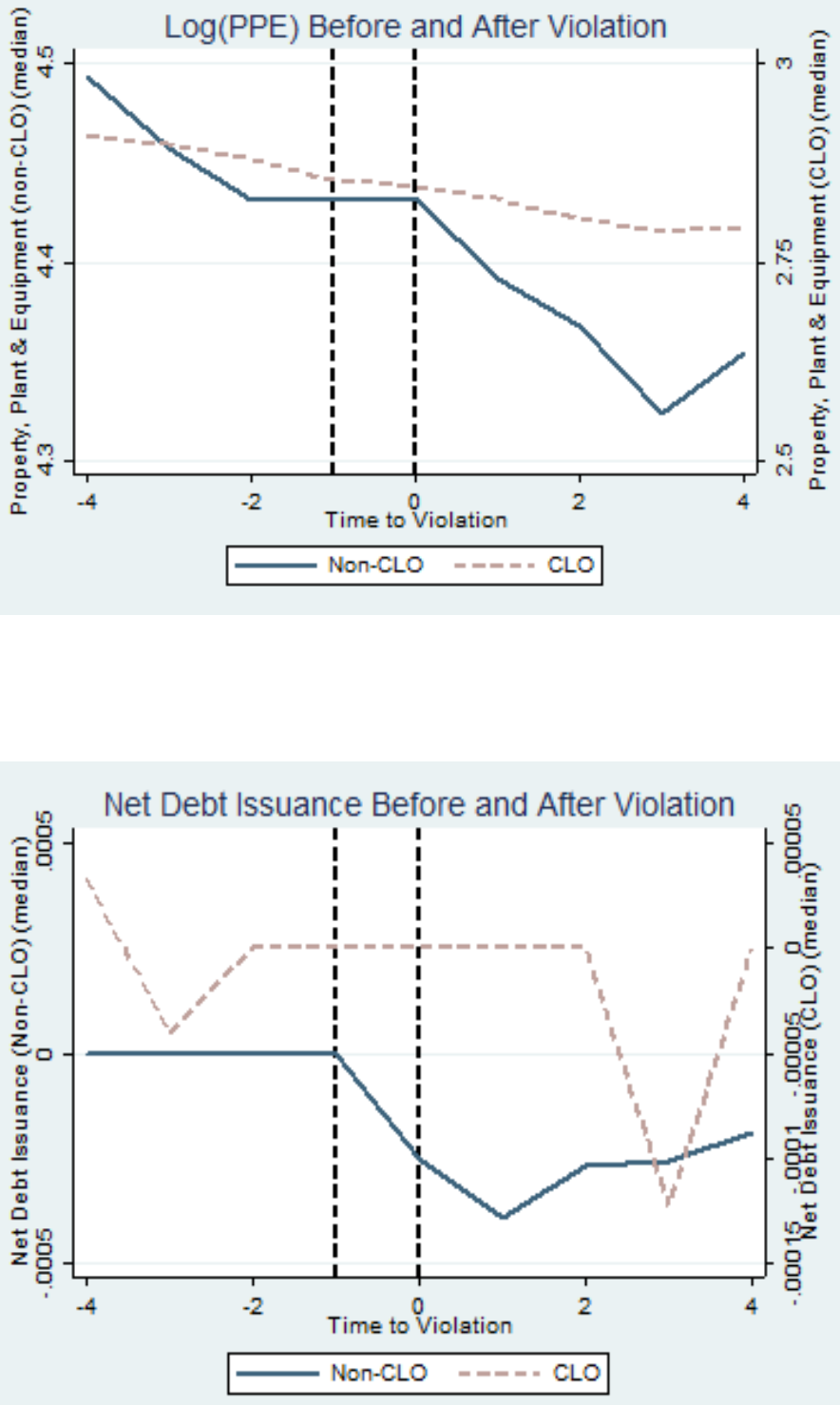

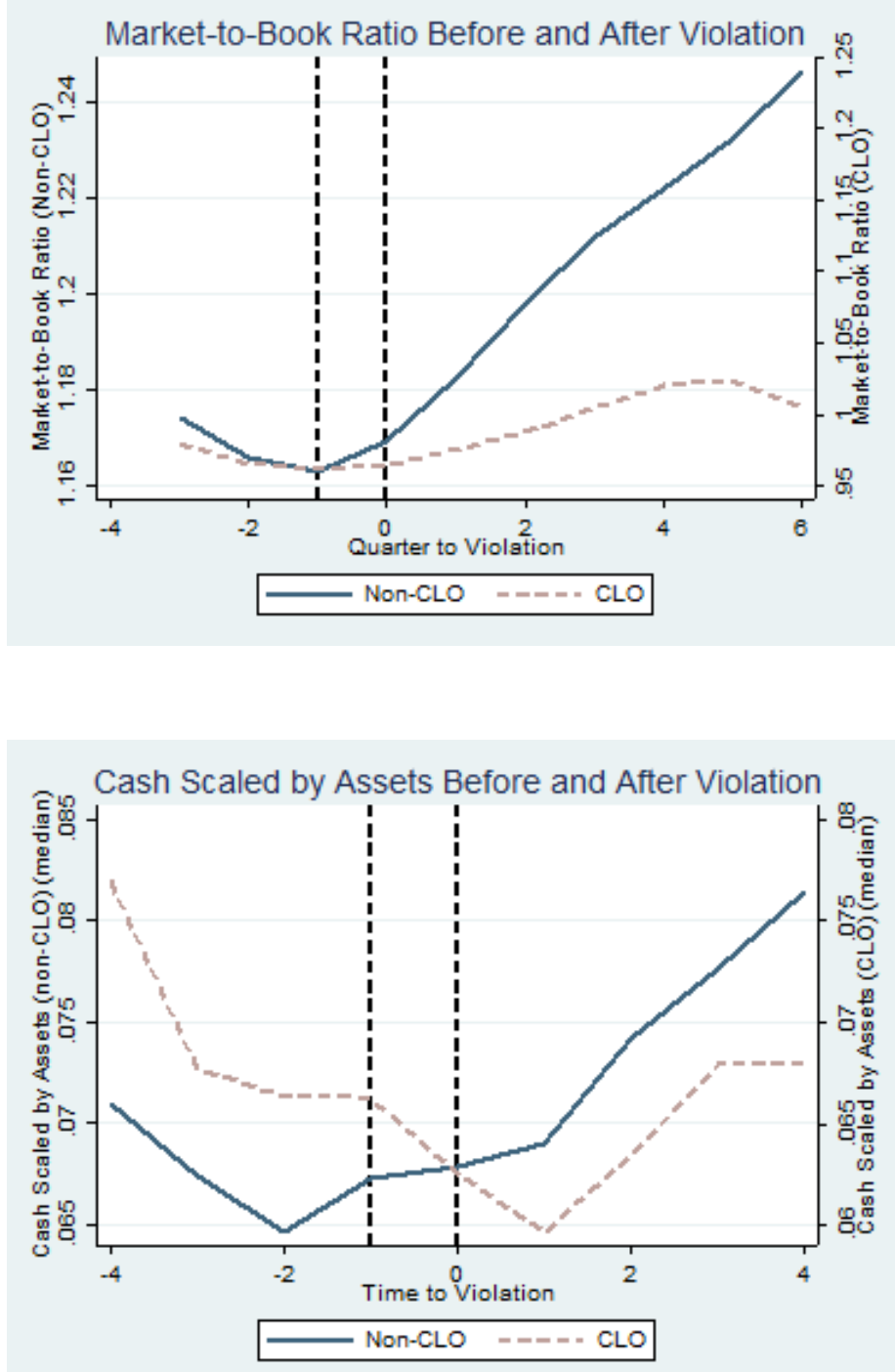

Most notable in these graphs is the difference between CLO and non-CLO loans. For most of the metrics, performance of CLO and non-CLO loans are roughly similar before the violation. At the time of the violation, these measures tend to change starkly for non-CLO borrowers, but less so (and 
sometimes not at all) for CLO borrowers. This is apparent in the difference between the solid line and the dashed pink line in each graph. The solid line in most of the graphs shows a sharp change immediately following the violation. In each case, the financial metric in question improves by four to six quarters after the violation. By contrast, the dashed line in several of the graphs does not change at all at the time of the violation, but continues the trend it was on before the violation. ${ }^{266}$ To the extent the dashed line does change, the measures of firms performance and financial responsibility either become worse, or improve far less by four to six quarters after the violation. After the violation, metrics continue to improve for non-CLO borrowers, but less so (and sometimes not at all) for CLO borrowers. Non-CLO included borrowers show signs of more financial investment conservatism (i.e., lower debt issuance, reduction in assets and shareholder payouts) and improvement in operating performance (better cashflow, lower operating expenses and a better market-to-book ratio). By contrast, CLO-included loans improve little if at all.

\section{Analysis of Data and Results}

These results support the hypothesis that creditors intervene less for borrowers with primarily securitized institutional loans. Borrowers whose institutional loans were included in CLO vehicles tended to have poorer performance in the four quarters following the violation than leveraged loan borrowers whose loans were not included in a CLO. In particular, with respect to investment and financial conservatism, loans that are put into CLOs show a pattern of increased spending and distribution of funds to shareholders after a violation, as compared to loans that are not put into CLOs. Even for metrics for which CLO and non-CLO loan borrowers

266 I note that the dashed line in the graph for Net Debt Issuance shows a temporary downward spike in the third quarter after the violation, but no change in the quarter of the violation or for two quarters afterward. Given that the scale of the dashed line in this graph (on the right side of the graph) is much smaller than the scale for the blue line, this apparent change is very small in magnitude and does not indicate a significant change in debt issuance for companies with securitized loans. 
exhibit similar performance metrics after four quarters, the CLO borrowers' financial metrics grew worse more quickly than for non-CLO loans, on average. For some of the performance measures, there is no discernable change in the outcome for CLO loans in response to the covenant violation. For the non-CLO loans, by contrast, the change in trend is apparent in the quarter of the violation or shortly thereafter. As already explained, these figures represent the raw data only, but the picture they paint is supported by a difference-in-difference analysis that shows that these different outcomes are statistically significant when controlling for a number of factors that might otherwise be relevant. 267

The results of the difference-in-difference analysis are presented in the appendix to the covenant violation data set. 268 This analysis is not intended to prove causality, but confirms that the data follows a pattern that is supported by theory. The test gives statistically significant results for most metrics, showing that the pattern in the raw data largely holds. The notable exceptions are cash acquisitions, total assets, cashflow scaled by assets and net debt issuance, the coefficients for which are not significant. With respect to the other financial outcomes, firms whose loans are sold to CLOs exhibit less financial and investment conservatism after a covenant violation, as compared to loans that are not put into CLOs. This suggests that lenders whose loans are put into CLOs have less incentives, or perhaps less leverage to force the kinds of changes on borrowers after a default that they have with other kinds of borrowers.

The differences between CLO and non-CLO covenant violators, in terms of both raw data and regression results are further described in the appendix to the covenant violation data set. ${ }^{269}$ The general pattern for all of these measures indicate that prior to the violation, both CLO and non-CLO violators' performance follows the same trend; after a violation, the results are consistent with the prediction that lenders

\footnotetext{
267 See McClane, supra note 216, at tbls. 9-11.

268 See id.

269 See id.
} 
intervene to positive effect for non-CLO borrowers, but that the same is not true for CLO borrowers.

\section{E. CEO/ Officer Turnover}

Another important way that lenders can influence corporate governance is by replacing high level officers like the CEO, President, or CFO of a borrower. As another test of the level of intervention that lenders undertake after a borrower's covenant violation, I examine whether a covenant violation is closely followed by a change in the borrower's CEO, president or CFO. Lenders often exert behind the scenes influence on borrowers after a violation or as a condition to waiving a violation. ${ }^{270}$ One way in which a lender might do this is by forcing a change in the borrower's leadership by insisting on the departure of the CEO or CFO. ${ }^{271}$ This mechanism of influencing corporate governance is particularly important when ordinary corporate governance mechanisms are weak and agency costs are high. ${ }^{272}$ In the pre-crisis period, a systematic pattern of such changes was observed for borrowers who had defaulted on their loans. ${ }^{273}$

In this Section of the analysis, I first investigate whether or not there is a systematic pattern of such CEO, President and $\mathrm{CFO}$ departures following a loan covenant violation. A pattern of departures suggests that lenders still exert influence on companies by forcing changes in their leadership in the post crisis era. Second, this Section examines departures with respect to borrowers whose loans are primarily held by non-banks, and those that are securitized.

In the first analysis I use a Cox proportional hazard model-an empirical test that assesses the probability of an

270 See Baird \& Rasmussen, supra note 1, at 1210-11.

271 See Tung, Unsung Influence, supra note 1, at 156-58; see also Baird \& Rasmussen, supra note 1, at 1209-12 (discussing lender intervention to force the removal of the CEO of Krispy Kreme); Mitchell Pacelle, Waiving or Drowning: Banks Face Loan Bind, WALl ST. J., Oct. 15, 2001, at C15 (recounting bank lenders' influence over the appointment of a chief restructuring officer at ANC Rental Corp., the parent company of car rental companies Alamo and National, following loan covenant violations).

272 See Tung, Unsung Influence, supra note 1, at 156-57.

273 See Nini et al., Creditor Control Rights, supra note 14, at 1741-46. 
event occurring at any given time, given a set of controls-to assess the baseline probability of a CEO, president or CFO turnover given the characteristics of a company, its financial performance, and the officer's tenure in his or her position. ${ }^{274}$ I use CEO, President and CFO sudden departures (what I will refer to collectively as "high-level departures" or "turnovers")-resignations that were not announced in news articles in the year leading up to the resignation, and I exclude any departure described as a retirement. Research on director and officer turnover has shown that such unannounced resignations are likely to be the product of an unplanned departure from the board, whereas retirements or announced departures are considered to be planned in advance. ${ }^{275} \mathrm{I}$ then calculate the difference between the baseline probability of a high-level departure and the probability of one occurring at a company that recently violated a loan covenant. As controls, I use several measures of financial performance to account for the fact that poor performing firms may be more likely to change CEOs. ${ }^{276}$

Companies that violate a covenant see a $34-40 \%$ greater likelihood of a turnover within the first three quarters following the initial report of the violation than firms that do not report a violation, using controls for the size of the company, average senior officer tenure, average senior officer age, and

274 See JefFrey M. Wooldridge, Econometric Analysis of Cross SECTION AND PANEL DATA, 686-93 (2002) (explaining the theory and usage of a hazard model).

275 See Dirk Jenter \& Fadi Kanaan, CEO Turnover and Relative Performance Evaluation, 70 J. FIN. 2155, 2163 (2015); see also Michael S. Weisbach, Outside Directors and CEO Turnover, 20 J. FIN. ECON. 431 (1988).

276 For a further discussion of these measures, see McClane, supra note 216, at tbl.12; see also Jenter \& Kanaan, supra note 275, at 2155-60; Weisbach, supra note 275, at 432, 438-42, 442 tbl.3, 446 tbl.5 (finding that more CEO retirements follow in the wake of poor performance, especially when the firm's board of directors is comprised of at least $60 \%$ independent directors). Some of this concern is mitigated by the fact that many exchange listing rules now require that listed companies have a majority of independent directors on their boards. See NYSE, Inc., Listed Company Manual § 303A.01 (2020); NASDAQ, Inc., Nasdaq Listing Rules § 5605(b)(1) (2020). Thus, all companies in the data will face similar dynamics. 
fixed effects for industry and quarter. ${ }^{277}$ These results support the contention that lender intervention is related to the departure of these senior officers.

Of course, it is not possible to determine definitively from the analysis whether the lenders are the main impetus for these individuals' departures. It is possible that these firm's conditions, while leading to a violation of a loan covenant, also lead naturally to management turnover. It is telling, however, that the probability of turnover is much higher in the quarter when the violation occurs or shortly thereafter, even though the financial condition of the borrowers tends to deteriorate beginning several quarters in advance of the violation itself. ${ }^{278}$

If the management turnover is due to lender intervention, the natural question is whether there is less of this turnover when lenders have less incentive or less bargaining power to effect these changes. I run the analysis again on subsets of loans that are held primarily by non-banks and those that are included in CLOs. In general, for the non-bank group there is no statistically significant difference. For the CLO group however, the effect is much smaller. An average CLO borrower had a $32 \%$ lower chance of having a CEO or president leave suddenly after a loan covenant violation than a non-CLO borrower. ${ }^{279}$

As a robustness check, I confirm that this is the case using the alternative specification for CLO loans, using the arranger market share in the CLO market as a proxy for lenders who are unlikely to be motivated to police borrowers. Once again, the results are consistent, and show a lower propensity for management changes. This finding suggests that when lenders securitize, they intervene less in the borrowing company's management. It may be an open question, at least as far the empirical analysis is concerned, whether lenders' intervention regarding a borrower's leadership is a good or bad thing. Nonetheless, given the results above showing that lender

277 See McClane, supra note 216, at tbl.12.

278 See discussion of the data and analysis supra Part III. The data shows that performance along several metrics begins to deteriorate prior to a violation, on average.

279 See McClane, supra note 216, at tbl.12. 
intervention is associated with better operating performance, ${ }^{280}$ it is reasonable to think that an engaged lender helping to make decisions about who occupies executive positions is beneficial on average.

\section{F. Robustness Checks of the Main Results}

In addition to the main analysis, I conduct a number of robustness checks to rule out possible confounding factors and support the main results. These tests are described below.

\section{Comparisons of the Loans}

The analysis above is not intended to show a causality. Rather, the raw data and the regressions are intended to show that outcomes diverge for some of the different groups of loans in question. This divergence remains statistically significant when controlling for the factors that account for borrower performance and that are often used in the empirical finance literature studying lender intervention. One possibility that must be addressed is that there is some inherent difference in the loans or borrowers that leads to the divergent patterns. For example, it is possible that the loans sold to non-banks and packaged into CLOs are fundamentally different than the loans for which banks retain a larger share of exposure, or that securitized borrowers need less intervention when violating loan covenants.

In order to address that possibility, I compare the loans of covenant violators in the various groups on observable characteristics to assess whether or not there is a significant difference between them. The comparisons are set out in the appendix to the covenant violation data set.281 Most of the observable characteristics of the loans and borrowers are not significantly different in any systematic way that could explain the divergent results. Notably, the three types of borrowers show no systematic divergence in terms of revenue, debt load, or size in terms of asset, market capitalization, age,

280 See discussion of the data and analysis supra Part III.

281 See McClane, supra note 216, at tbl.14. 
or credit rating. ${ }^{282}$ Nonetheless, it is possible that some unobservable characteristic drives the results. For instance, some companies might inherently need less intervention. ${ }^{283}$ However, it is not clear why lenders would choose to unload risk from debtors that need less help following a violation, or are likely to commit only technical violations that do not require lender guidance. It is also unclear why lenders would choose to keep risk from debtors that need more help or are more likely to commit serious violations. Moreover, if the securitized group of debtors needed less intervention, it does not explain why their financial performance declines or improves less than that of firms for which intervention takes place. I also note that, even if there were some systematic but unobservable way in which the two types of borrowers diverged, it would still be important that lender intervention has diminished for one particular class of borrower.

\section{Non-Bank Loan Concentration}

The analysis above divided the covenant violators into different, mutually exclusive samples based on whether their loans are primarily held by non-banks, and whether any of their loans are included in CLOs. However, the borrowers in the CLO sample have, on average, leveraged loan debt that is much more heavily concentrated in the hands of non-bank financial institutions than those in the non-CLO sample.

282 See id.

283 Indeed, a recent paper posits that some covenant violations are "foot faults," meaning that they are technical or incidental violations by otherwise strong companies that do not require lender guidance. See Thomas Griffin et al., Losing Control? The 20-Year Decline in Loan Covenant Restrictions 2-3 (Dec. 2019) (unpublished manuscript), https://ssrn.com/abstract $=3277570$ [https://perma.cc/4KRL-FV6T]. The authors develop a model to determine what types of violations are serious (which they call "true positives") and which types are only foot faults (which they label "false positives"). The authors determine that since the financial crisis, most violations are situations in which the lender should step in. See id. I note that this paper lends support to the bank abdication hypothesis examined here; if most post-crisis violations are situations in which lenders should intervene, then the lack of lender intervention is all the more striking, and cannot be easily dismissed as a spurious or false positive violation. 
Specifically, $76 \%$ of the total loan debt for the average borrower in the CLO sample is in the form of term loans held by non-bank institutions, according to the loan-type classifications in the DealScan data. By contrast, between $45-60 \%$ of the loans made to non-CLO borrowers on average are term loans, depending on the year. This raises the possibility that the results are driven by non-bank institutions generally, and are not specific to CLOs. That possibility would be consistent with the hypothesis that bank lenders have less interest in monitoring debtors to whom they have less exposure, and that non-bank lenders holding TLBs either have less interest in monitoring, or hold cov-lite loans that make it more difficult to monitor and intervene in borrowers' governance.

I first note that this possibility does not reduce the importance of the results above. It would still be true that lender intervention is fading as the nature of leveraged lending changes; the difference would be in the interpretation of which type of lender-borrower relationship this trend reflects. However, I attempt to tease the effect of loan securitizations apart from the effects of the originate-to-distribute trend and the increased participation of non-bank lenders in the market generally, using an additional methodology.

To do this, I use a triple-difference analysis using financial metrics discussed above as outcomes. ${ }^{284}$ In doing so I analyze the differences in financial metrics following a covenant violation for both CLO borrowers, and for the universe of covenant violators, $76 \%$ or more of whose debt is held by non-bank institutional lenders. The $76 \%$ threshold is chosen because that is the average concentration of non-bank loans for borrowers in the CLO sample, and the aim of this robustness check is to assess whether or not CLO borrowers obtain different outcomes than other borrowers with a large proportion of nonbank loans. The triple difference analysis assesses whether there are statistically significant differences between these groups and the control group (borrowers with lower concentrations of non-bank loans) and between each other. As in the main analysis, my purpose is not to show causality, but simply III.

284 The financial metrics used in the analysis are described supra Part 
to assess whether there are statistically significant differences that would be consistent with what theory would predict.

The results of the triple difference analysis are shown in the appendix to the covenant violation data set. ${ }^{285}$ For several of the financial metrics, the results for the CLO group remain statistically significant, supporting the hypothesis that interventions are diminished for the borrowers included in CLOs, even as compared to other borrowers whose debt is held by non-bank lenders. ${ }^{286}$ Not all financial outcomes remain statistically significant. ${ }^{287}$ This could be due to the fact that, because CLOs hold the vast majority of leveraged loans, it is difficult to disentangle the effects of their loan ownership from the effects of having a high concentration of loans held by nonbank lenders generally, at least for some kinds of interventions. To the extent that there is a difference between CLOs and other non-bank lenders, this could be because other nonbank lenders are more active in monitoring borrowers, or because they have longstanding or repeat-player relationships with banks that induce banks to engage in more monitoring than they otherwise might.

\section{G. The Relationship Between Structured Finance and Corporate Non-Governance}

The foregoing analysis shows that there has been a withdrawal of lender involvement with respect to some borrowers, and the withdrawal is related to the rise of loan securitization. The pattern that emerges from the data is summarized by Figure 6 below. Figure 6 shows two trends: the vertical bars show the volume of CLOs issued between 2008 and 2018 (denoted in billions of dollars, along the left-hand y axis); the black line signifies the difference in lender intervention over time between CLO borrowers versus borrowers not in the CLO group. Specifically, the black line represents the difference in improvement of borrowers' performance (measured with market-

\footnotetext{
285 See McClane, supra note 216, at tbl.14.

286 Id.

$287 I d$.
} 
to-book ratio) between CLO and non-CLO borrowers, four quarters following a covenant violation (demarcated on the right-hand side). ${ }^{288}$ While other measures analyzed above could be used to create a similar graph, the market-to-book ratio was used since it captures many elements of company value.

The higher the black line on the graph, the greater the gap in intervention between CLO and non-CLO borrowers. In other words, the higher the black line, the lower the corporate governance benefit that borrowers of securitized loans realize, relative to non-securitized loan borrowers after a covenant violation. This graph uses differences in the raw data without any controls, but as previously explained, the differences remain in regressions with numerous controls.

288 This is the ratio between the market value of the firm's equity (i.e., what investors think the company is worth) and the value of the firm's net assets on its balance sheet (i.e., the historical value of its assets at the time of their acquisition). It is often used as a measure of firm performance. See, e.g., Lucian Bebchuk et al., What Matters in Corporate Governance?, 22 REV. FIN. STUD. 783, 800-01 (2009) (using a market-to-book ratio as a measure of firm value). 


\section{Figure 6: CLO Issuance and Performance Difference Between CLO and Non-CLO Issuers ${ }^{289}$}

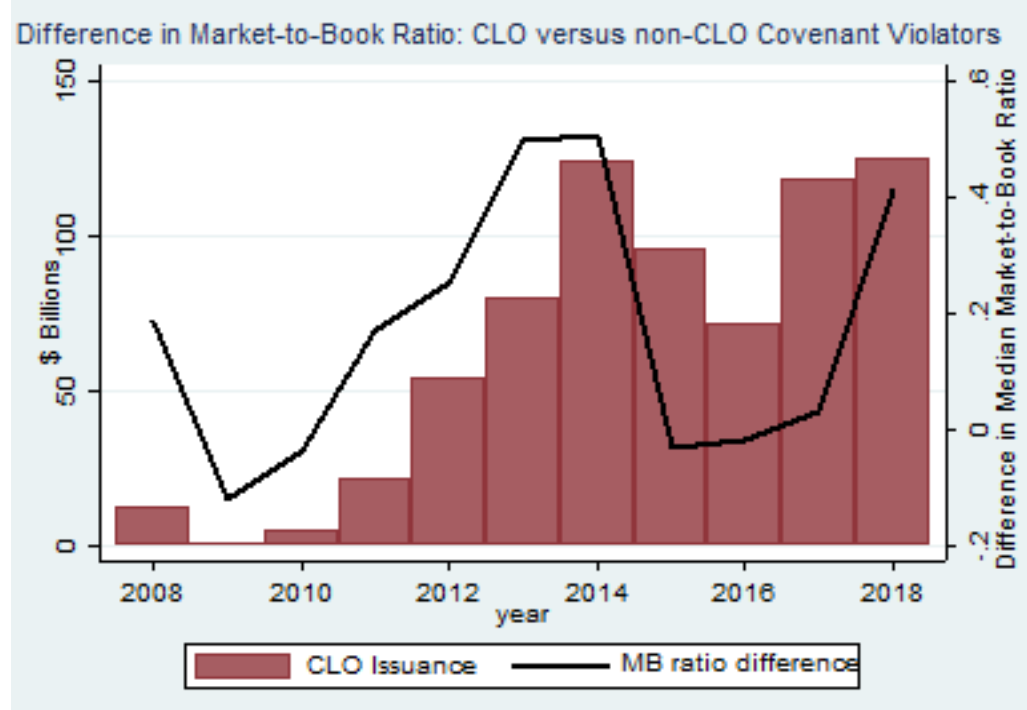

The figure is a snapshot of the difference in lenders' corporate governance intervention over time between loans that are securitized and those that are not. Notable from the figure is that the difference between post-violation performance of CLO loans versus non-CLO loans tracks the volume of CLO issuance. This is the exactly the pattern one would expect to see if there was a change in creditor governance driven by securitization: lenders' intervention varies in tandem with the demand for loans to bundle into CLOs. ${ }^{290}$ This general finding supports one of the main hypotheses predicted by the discussion of lender incentives in Part I: namely, that incentive changes created by structured finance have led to a

289 This figure summarizes information included in the data set created by the author. See McClane, supra note 216 .

290 The fact that the differences in interventions run slightly ahead of the CLO issuances also makes sense given that loans are "warehoused"purchased from lenders and placed into an SPV-for up to year before the CLO notes themselves are issued. See Benmelech et al., supra note 151, at 96-97. 
withdrawal of lenders from corporate governance intervention for a large and growing class of corporate debt. ${ }^{291}$ The withdrawal of lenders exposes a gap in the common understanding of how corporate governance functions, and this gap has real consequences for the management of firms.

A few realities complexify this narrative and must be addressed for a complete understanding of the results. First, the Dodd-Frank Act passed in the wake of the financial crisis attempted to mitigate some of the problems of securitization described here through risk retention rules. ${ }^{292}$ The so-called "skin-in-the-game" provision of Dodd-Frank did not address corporate governance directly, but required that lenders who offload loans to securitization vehicles (like a CLO or lending bank) keep some percentage of the loan interest, in order to give originators an incentive to care about the terms on which they make loans. ${ }^{293}$ This provision might confound the narrative that CLOs disrupt lender intervention for a few reasons. First, because it would mean that CLOs are required to retain enough of an interest in the loans they hold such that they would be incentivized to take an interest in borrowers' management (either directly or indirectly by pressuring relationship banks). This would also mean that CLOs could not easily trade away the entire portion of a troubled loan to avoid having to deal with the borrower. Second, it might mean that relationship lenders that frequently originate the loans would be forced to hold onto a large enough portion of borrowers' credit risk that they would also have a greater incentive to participate in governance than the narrative in Part I would imply.

291 See discussion supra Part II.

292 See Dodd-Frank Wall Street Reform and Consumer Protection Act, Pub. L. No. 111-203, § 941(b), 132 Stat. 1376, 1890-96 (2010) (codified at 15 U.S.C. $§ 780-11$ (2018)) (setting out risk retention requirements and mandating several federal agencies enact rules to implement them).

293 See Credit Risk Retention, 79 Fed. Reg. 77,602, 77,604-05 (Dec. 24, 2014) (to be codified at 12 C.F.R. pts. 43, 244, 373, 24 C.F.R. pt. 267) (stating that " $[\mathrm{b}] \mathrm{y}$ requiring that a securitizer retain a portion of the credit risk of the securitized assets, the requirements of section $15 \mathrm{G}$ provide securitizers an incentive to monitor and ensure the quality of the securitized assets underlying a securitization transaction, and, thus, help align the interests of the securitizer with the interests of investors"). 
However, there are several issues with the Dodd-Frank risk retention rules that make it less likely that they would affect the lender governance implications of this study. First, the rules specify a percentage of the risk that must be retained but say nothing about covenants or other terms that loans must include. ${ }^{294}$ Thus, they do nothing to strengthen the leverage a creditor has, even if they might strengthen a creditor's incentives. Second, the percentage lenders are required to retain is fixed, and arguably does not provide adequate incentives for monitoring in all cases. Originators are required to retain $5 \%$ of the loans they originate, ${ }^{295}$ and some contend that this amount is too low to provide adequate screening or monitoring incentives. ${ }^{296}$ Even with risk retention, the risk that any one firm poses in a portfolio may be too little to give lenders, much less structured finance vehicles, the requisite leverage to intervene or the incentive to invest disproportionate resources in the governance any single borrower.

Third, and most importantly for CLOs, a recent court decision by the D.C. Circuit invalidated Dodd-Frank's risk

294 Id. at 77,603.

295 See Dodd-Frank Wall Street Reform and Consumer Protection Act $\S 941(b), \S 15 \mathrm{G}(\mathrm{c})(1)(\mathrm{B})(\mathrm{i})$. The rules which went into effect December 24, 2015 for residential mortgage securitizers and December 24, 2016 for other types of securitizations (including CLOs) require originators to retain a total of $5 \%$ of an eligible horizontal residual interest (an interest in the most subordinate claim to payments of both principal and interest), an eligible vertical interest (an interest in each class of the asset-backed security in the transaction that constitutes the same portion of each class) or some combination of the two. See Credit Risk Retention, 79 Fed. Reg. at 77,604-08.

296 See, e.g., Craig Furfine, The Impact of Risk Retention Regulation on the Underwriting of Securitized Mortgages, J. Fin. Serv. Res. (Mar. 15, 2019), https://link.springer.com/content/pdf/10.1007/s10693-019-003086.pdf [https://perma.cc/DCB6-SPEU]. See also Henri Pagès, Bank Monitoring Incentives and Optimal ABS, 22 J FIN. INTERMEDIATION 30, 47 (2013) (arguing that a one-size fits all five percent requirement is inadequate to account for the differing risks of securitizations); Guixia Guo \& Ho-Mou Wu, A Study on Risk Retention Regulation in Asset Securitization Process $45 \mathrm{~J}$. BANKING \& FIN. 61, 61-62 (2014) (developing a model of securitization risk, and arguing that regulation mandating a fixed level of risk retention increases adverse selection by reducing the information conveyed by securitization decisions). 
retention rules with respect to "open market" CLO managers. ${ }^{297}$ Open market CLO managers are those that acquire loans from other originators, as opposed to banks or funds that sponsor their own CLOs (called "balance sheet CLOs," for whom the risk retention rules were held to still apply). Open market managers are estimated to account for 90\% of CLOs in the U.S. as of late 2019. ${ }^{298}$ Thus, a little more than a year after the risk retention rules went into effect for CLO managers they were effectively vacated for the vast majority of them, leaving most CLOs exempt from the protections those rules were intended to provide. ${ }^{299}$ The existence of these rules is therefore consistent with lenders' withdrawal from intervention, even though the rules were intended, in part, to prevent that from happening.

\section{DISCUSSION AND PROPOSALS}

Two broad patterns emerge from the analysis that carry implications for corporate law and financial regulation. First, the results show that lender influence on corporate management is strong in the post-crisis era for leveraged companies whose debt is not concentrated in CLOs. Second, the results are consistent with the hypothesis that loan securitization and the high demand for corporate debt to fuel CLOs have reduced lenders' ability or willingness (or both) to exert their influence on corporate governance for some borrowers. A complete consideration of the implications of these findings would require more space than is feasible to accommodate in this Article. Nonetheless, in the Sections below I highlight some of

297 See Loan Syndications Trading Ass'n v. SEC, 882 F.3d 220 (D.C. Cir. 2018)

298 See Fin. Stability Bd., Vulnerabilities, supra note 2, at 35.

299 The D.C. Circuit's decision may not matter in any event: despite the risk retention rules, CLO managers retain an interest in the lowest rated equity tranches of their structures in about $50 \%$ of deals. See Fin. STABILITY BD., Vulnerabilities, supra note 2, at 35. The portfolio nature of CLOs' investment in equity tranches arguably dulls their incentive to invest disproportionate resources in any one borrower at a time, and therefore CLO managers may not see a need to do anything about a covenant violation, even when they can. 
the prominent ones, consider possible ways to address these developments, and mark out avenues for future research.

\section{A. Agency Costs and Shifting Corporate Governance}

An initial point that should be addressed is whether a trend toward less lender control over corporate behavior is really a problem for corporate governance. The point was touched upon in the background discussion, but the results above urge further consideration of it. With American companies' debt at record levels, ${ }^{300}$ and a large and growing amount funneled into securitization, ${ }^{301}$ it might seem as though a check on borrowers' financial health would be helpful both for corporate governance and the financial system generally. The COVID-19 crisis and the experience of indebted companies in the ensuing financial downturn has starkly highlighted the value of corporate debt management, although an economic downturn has been predicted for years and might have arrived in any event. Nonetheless, decisions driven by lenders' interests may not always be in the best interests of all corporate stakeholders, even in a downturn. It is possible that lender restraint is better than activism from a shareholder's perspective, at least in some situations.

As discussed above, corporate governance is concerned with agency costs, defined as the divergence of interest between corporate manager-agents and shareholder-owners. ${ }^{302}$ However, lenders are primarily concerned about what are known as the agency costs of debt-that is, the divergence between the interests of company managers (and possibly shareholders) and the interests of the creditors. ${ }^{303}$ Under certain

300 See Frank Holmes, What Ballooning Corporate Debt Means for Investors, FORBES (Apr. 8, 2019), https://www.forbes.com/sites/greatspeculations/2019/04/08/what-ballooning-corporate-debt-means-for-investors/\#45c18a636c80 [https://perma.cc/VS2L-QTP2].

301 See CLO Market Makers, supra note 260 (showing data on the volume of securitization each year). See also Fin. STABILITY BD., VulnerabiLITIES, supra note 2 , at 6-7.

302 See supra notes 26-38 and accompanying text.

303 See Bratton, supra note 97, at 466-68. 
conditions, the interests of debt holders and shareholders may conflict. 304

Although shareholder and debt holder interests are undoubtedly aligned at times, the agency cost story is complex. Typically, controlling agency costs is conceived of as giving management incentives to invest in productive projects and refrain from using the corporation's resources for unproductive, self-serving ends. ${ }^{305}$ Earlier research in financial economics argues that the kinds of interventions lenders make (like reducing capital expenditures, acquisitions, or shareholder payouts) place such restraints on management and are therefore unqualifiedly good for firm governance; however their measure of what is "good" depends largely on short-term equity market valuations and performance without taking into account any potential countervailing tradeoffs. ${ }^{306}$

304 See George Triantis, Exploring the Limits of Contract Design in Debt Financing, 161 U. PA. L. REV. 2041, 2042 (2013) ("Most notably, as faithful agents of their shareholders, managers are more likely to (a) forego lower-risk, profitable projects ('underinvestment'); (b) invest in higher-risk, unprofitable alternatives ('overinvestment' or 'risk alteration'); (c) incur additional debt to further leverage the equity in the firm; and (d) distribute firm value to shareholders in the form of dividends or share repurchases."). This would be especially problematic if, as has been argued, managers have become more aligned with shareholder interests in recent years. See Edward B. Rock, Adapting to the New Shareholder-Centric Reality, 161 U. PA. L. REV. 1907, 1910 (2013) (noting that "managers and directors today largely 'think like shareholders"').

305 See Triantis \& Daniels, supra note 1, at 1077-80.

306 See, e.g., Nini et al., Creditor Control Rights, supra note 14, at 1715-16, 1719-20. The article states that "[t]he interpretation of the consequences of creditor control crucially depends upon the subsequent impact of creditor intervention on borrower performance. We find evidence that both operating performance and equity-market valuation improve, on average, following a financial covenant violation." Id. at 1716. Even accounting for the article's statements of agnosticism regarding the benefits of creditor intervention, its language elsewhere suggests an assumption that such interventions are good. For example, the article discusses lenders' assertion of control over firm decisions as "[s] uggested fixes" for firm problems and "affect[ing] more substantial changes" like the "hiring of a turnaround management firm" for companies "suffering from deep[] structural problems." $I d$. at 1716 . The article lacks a discussion of the potential conflicts with shareholder interests (such as the desire for higher payouts), except implicitly by suggesting short-term firm value ought to be considered as a measure 
It is axiomatic that governance also involves the monitoring of agency costs with respect shareholders, whom lenders may care little about or whose interests they may oppose. Some of the results of the analysis discussed in this Article could be viewed as having a negative impact on corporate governance when viewed from this perspective, because they indicate that lenders sometimes take actions which may conflict with shareholders' interests. For example, lender intervention (when it happens) tends to result in lower levels of total debt and debt issuance, ${ }^{307}$ which is good for debt holders because it means the borrower will be more likely to pay its debts. However, the finance and law literatures have pointed out that debt can sometimes constrain agency costs by leaving management without free cash flow to waste, thus imposing discipline that is good for shareholders. ${ }^{308}$ In effect, debt can be a governance mechanism (independent of the borrower's relationship with the lender) because it incentivizes management to work more efficiently, and arguably create more value for the firm's equity holders. ${ }^{309}$

Similarly, shareholder payouts, such as dividends or share buybacks, may be viewed as a sign of managerial fidelity to shareholders, even if it might increase risks for debt holders. ${ }^{310}$ To take another example, while lower levels of corporate acquisitions certainly signal more investment conservatism, such conservatism may not be in the best interests of all stakeholders if the acquisitions could produce higher returns

of the success of a creditor intervention. See id. But it states that its "results suggest that effective creditor interventions can boost, or even substitute for, equity-centered governance," and in its theory and background section compares creditor intervention favorably to activism by equity holding hedge funds, citing studies that hedge fund activism results in positive short-term gains. Id. at 1717-20.

307 See supra Part III; see also Nini et al., Creditor Control Rights, supra note 14.

308 See Michael C. Jensen, Agency Costs of Free Cash Flow, Corporate Finance, and Takeovers, 76 AM. ECON. REV. 323, 324-25 (1986) (arguing that issuing large amounts of debt could help reduce the agency costs of public company management by strengthening management's incentives to maximize firm value).

309 See id.

310 See Bratton, supra note 29, at 51-52. 
than would be realized otherwise. Creditors are more risk averse than shareholders, because they will enjoy the upside of any risky venture only to the point at which they get paid back, but they will absorb the downside risk if the venture falls through and the loan is unpaid. By contrast, shareholders enjoy all the surplus of a risky venture, and if the firm is already in financial distress, they will be no worse off if the venture falls through. Thus, what might be good corporate governance (in the sense of reducing the agency costs of debt) for a lender may be less so for shareholders.

Despite the arguments that lender intervention sometimes increases agency costs with respect to shareholders, there are important reasons to believe that it is generally beneficial. Even if the interests of debt holders and shareholders do sometimes conflict, they conflict only to the extent that the costs to shareholders of lender intervention do not outweigh the benefits. This balance favors lender intervention as a positive corporate governance mechanism in several respects. First, lenders possess expertise at managing debt and maintain relationships with borrowers that can help them to manage the debt well. Remaining free of financial distress is often in the interests of shareholders as much as in the interest of lenders.

Moreover, even if certain corporate decisions would be good for stockholders in the short run, it is useful to have a mechanism that can check management opportunism when it comes to the long run interests of shareholders (and other corporate stakeholders such as employees). For example, if a company borrows money to execute a stock buyback (a common scenario today $^{311}$ ) it might be good in the short term for shareholders. ${ }^{312}$ Such moves may not be good for companies in the long run, however. ${ }^{313}$ Indeed, the fallout of the COVID-19 pandemic has

311 Ben Holland \& Liz McCormick, Companies Use Borrowed Billions to Buy Back Stock, Not to Invest, BloomberG (Aug. 8, 2019), https://www.bloomberg.com/news/articles/2019-08-08/companies-use-borrowed-billions-to-buy-back-stock-not-to-invest [https://perma.cc/F77STPAN].

312 See Bratton, supra note 29, at 51-52.

313 See Jesse M. Fried, Insider Trading Via the Corporation, 162 U. PA. L. REV. 801, 804-05 (2014) (referring to stock buybacks as "indirect insider 
illustrated the dangers for companies that borrow excessively to buy back shares, or those who return excessive amounts to shareholders for a short-term windfall. The law currently has no check on such practices, but lenders, who are experts at assessing the risks and rewards of projects undertaken with debt, play a valuable role in allowing such moves when they are warranted, and preventing them when they are overly risky.

Given the fact that lender interventions have been found by other researchers to lead to healthier financial metrics, including better market-to-book ratios, ${ }^{314}$ and higher abnormal returns $^{315}$ (both signals of higher overall firm value), it stands to reason that the conflict between shareholders and lenders' interests are often outweighed by the benefits lenders bring to the table.

Ultimately, whether lender intervention is good or bad for corporate governance depends on which stakeholder's perspective one takes in a given set of circumstances. There may even be other stakeholders, such as employees or consumers, who, while not ordinarily part of the agency cost analysis, may have important interests that are affected by creditor governance. Resolving these issues is beyond the scope of this Article, and future research may clarify whether and when lender interventions are helpful for various stakeholders and when they are not. For present purposes, even if waning lender intervention is sometimes bad for shareholders, it creates externalities that implicate financial regulation, as discussed in the next Section.

\section{B. Intertwined Corporate Governance and Financial Regulation}

A withdrawal of lenders from corporate governance has troubling implications for the regulations that were intended to limit risk in financial products like CLOs. The results above suggest that lender intervention is related to financially

trading" with harmful consequences for shareholders).

314 See Nini, et al, Creditor Control Rights, supra note 14, at 1747-51.

315 See id. at 1751-58. 
healthier borrowers, on average. This means that if lenders intervene less often for securitized borrowers, then the assumed equilibrium in which CLOs' risk of default is priced and traded may not take into account factors that could shift that risk dramatically. I explain the consequences of this below.

CLOs frequently have been distinguished from their more infamous relatives, CDOs, which bore some of the blame for exacerbating the financial crisis. ${ }^{316}$ There are two main arguments frequently advanced for why CLOs are safer, and pose far fewer risks than CDOs. The first argument is that the quality of the underlying loans that go into the securitization vehicles of CLOs is better. ${ }^{317}$ Before the financial crisis, CDOs consisted of securities that were themselves backed by home mortgage loans. ${ }^{318}$ Observers and market participants have noted that CLOs are different than CDOs due to the types of loans, and the creditworthiness of the underlying borrowers of these loans who are less vulnerable to rising interest rates or other problems that caused mortgage borrowers to default during the financial crisis. ${ }^{319}$ Studies of CLOs created in the pre-crisis period found that the loans in these vehicles indeed had low rates of non-payment default. ${ }^{320}$ Relatedly, some argue that CLO structures are safer because the loans that go

316 See Sally Bakewell, Insurer Makes Big Bet on Wall Street's Loan Machine, BlOOMBERG, (Nov. 26, 2018), https://www.bloomberg.com/news/articles/2018-11-26/clo-island-insurer-makes-big-bet-onwall-street-s-loan-machine [https://perma.cc/HF4C-BR3M] ("[T]hose in the industry say CLOs are different. The underlying loans to firms aren't as vulnerable to rising interest rates as subprime home borrowers a decade ago.").

317 Id

318 See Robert Pozen, Too Big to Save?: How to Fix the U.S. FinanCIAL System 73-75, 83-84 (2010).

319 See Bakewell, supra note 316.

320 See Benmelech et al., supra note 151, at 91-92 (concluding that, for the period from 2005-2007, securitization was "not statistically significant in predicting poor [loan] performance" but finding some evidence of poor loan performance in the second year of the dataset, perhaps owing to "overheated market conditions driven by large CLO issuance[s] and institutional investors' demand for corporate loans more broadly" (citation omitted)). See also Bakewell, supra note 316 ("Among the more than 1,500 U.S. CLOs rated by S\&P Global Ratings since 1994, only 36 tranches across 21 transactions had defaulted as of mid-2018.”). 
into CLOs are secured (i.e., have collateral that a lender could seize if the borrower doesn't pay) and that the collateral consists of corporate assets that are higher quality than home mortgage loans are. ${ }^{321}$

Second, some argue that CLOs are less risky because loan participations are sold piecemeal to CLOs, and that some of the loan risk is kept by the original lead lender, in contrast to home mortgage loans that are usually transferred wholesale to CDO vehicles. ${ }^{322}$ Therefore, lenders retain an interest in monitoring and policing the borrower. This stands in contrast to mortgage lenders who, prior to the financial crisis, were able to offload the risk of the loans they made completely. ${ }^{323}$

These arguments and some of the data that backs them up are indeed comforting. However, there are still reasons to be concerned, particularly in light of the findings above. With respect to arguments about the stability and safety of the underlying loans, it is important to remember that before the financial crisis, it was widely assumed that mortgage loans were also quite safe because default rates were relatively low and the underlying assets (houses) had gone up in value for decades. ${ }^{324}$ Thus, the loan collateral of CDOs was assumed to be a reliable fallback for lenders in case the borrowers failed to pay. ${ }^{325}$ CLO loans are different, but the arguments and

321 See Benmelech et al., supra note 151, at 92-95.

322 See, e.g., Tung, Unsung Influence, supra note 1, at 165 ("As far as loan sales, the lead bank typically does not sell its stake, preferring instead to preserve its relationships with both the borrower and its syndicate members, who not only depend on the lead bank for monitoring services, but likely agreed to join the syndicate relying at least in part on the lead bank's continuing involvement in the loan."). But see Bord \& Santos, supra note 88, at 28-29 (noting that in the pre-crisis period lead banks sold all but 3-6\% of their term loan stakes, while keeping most of their revolving facility stakes)

323 See Pozen, supra note 318, at 49-51. Tung, Unsung Influence, supra note 1 , at $129-30,165-66$.

324 Pozen, supra note 318, at 83-84 ("Because the trend line [for house prices] was positive for the decade before 2004, the models gave short shrift to the likelihood of a drop in U.S. housing prices. When Steve Eisman, a professional investor, asked his contact at Standard \& Poor's what would happen if real estate prices fell, the man's reply was that his 'model for home prices had no ability to accept a negative number."').

325 See id at 75, 83-84. 
evidence about their safety should be taken cautiously. Studies surrounding the safety of CLO vehicles cover limited time periods-usually two or three years-and one prominent study found some limited evidence of the adverse selection of loans used as collateral in one year, which the authors claim could be the result of an overheated market for CLOs. ${ }^{326}$ More importantly, however, even if it is true that the underlying loans are of good quality when they are placed into the CLO vehicle, the analysis of the riskiness of the CLO itself fails to take into account the negative corporate governance effects that the CLOs themselves help to create. Specifically, the opinions about the safety of CLOs and their underlying collateral rely on historical assumptions, but those assumptions do not take into account the equilibrium effects of the CLOs themselves, namely, the undermining of lenders' monitoring incentives that lead borrowing companies to become less financially sound.

Even if the effect is small in terms of the probability that a borrower will be unable to pay on a loan, the effects for a CLO or any complex structured product can be large. A numerical example illustrates. Assume that a CLO is constructed using 100 corporate loans. The structure is tranched, meaning that the terms of the investment state that losses are not shared equally. ${ }^{327}$ Rather, for the first ten loans to default, whatever they may be, the losses will be borne by the lowest level investor (for purposes of illustration, "Investor 1"). For the next ten loans to default, losses will be borne by the next higher level investor ("Investor 2"). Investors 1 and 2 will be purchasing investments with a higher credit rating than any of the underlying loans themselves.

Assume further that the probability of default of any one loan is $5 \%$. Also assume that the odds of any one borrower defaulting on its loan are completely unrelated to the default of any other borrower (this is a simplifying and unrealistic assumption, but CLO portfolio managers often attempt to structure a diverse portfolio so that the probability of default of the

326 See Benmelech et al., supra note 151, at 92.

327 See POZEN, supra note 318, at 73 (describing CDO tranching generally); Fin. Stability BD., Vulnerabilities, supra note 2, at 33, 34 fig.B.1. 
individual loans are as uncorrelated as possible ${ }^{328}$ ). Before Investor 1 loses any money, ten loans have to default. The odds of this happening can be determined according a formula, the binomial distribution formula, that determines the cumulative odds of a sequence of unrelated events. ${ }^{329}$ If the odds of any one loan defaulting are $5 \%$, the odds of ten total loans defaulting is $2.82 \%$. Thus, Investor 1 has effectively taken a loan with a default risk of $5 \%$ and turned it into an investment with only a $2.82 \%$ of defaulting. The investment will likely get a higher credit rating and be safer than investing in any individual loan.

If ten tranches like Investors 1's are bundled together to make another, even safer tranche, it will have a probability of default that is even lower: $0.05 \%$. If Investor 2 buys this tranche, she can be secure in the fact that is it is expected to default only once every 10,000 years. That is fairly safe by most standards.

However, suppose that the real risk of default is $6 \%$ instead of $5 \%$. This is a small increase in risk of one percentage point for each individual loan that goes into the CLO portfolio. The effect is magnified in the risk of the CLO tranches: Investor 1 's risk of default goes from $2.82 \%$ percent to $7.75 \%$, more than double the risk of the original security, and more than the risk of default of any individual loan. Investor 2 is even worse off: her default risk goes up to $24.7 \%$. If we assume that the real risk of an individual loan's default is $7 \%$, just one more percentage point higher, Investor 1's default risk goes to $16.2 \%$, and Investor 2's risk goes to $97.19 \% .{ }^{330}$ Thus, these erstwhile low-risk investments in fact quickly become quite risky.

CLOs in the market are more complex than this stylized example, but it nonetheless drives home the point that very

328 Fin. Stability BD., Vulnerabilities, supra note 2, at 3-4 ("To promote diversification, CLOs are structured with specific investment limitations that the CLO manager must adhere to, such as issuer and industry concentrations, which are intended to protect investors from potential losses through risk diversification.").

329 See Alexander Holmes et AL., InTroductory Business Statistics 206-07 (2017) (discussing binomial distributions).

330 This example is adapted from one often told by Robert Pozen. The anecdote is partially recounted in PozEN, supra note 318, at 95-96. 
small changes in the default risk of individual loans can have a large impact on the ultimate investment product created out of them. That can translate into systemically important risks. Moreover, the example above assumes that defaults are uncorrelated, an assumption that is unlikely to be true in reality, especially in times when the economy as a whole is in distress. CLO managers and underwriters undoubtedly understand this and structure their portfolios and tranches accordingly. ${ }^{331}$ Rating agencies also take it into account in their models when they rate the riskiness of CLOs. ${ }^{332}$

However, the assumptions underlying these models, in particular the correlation between individual loan defaults, is likely to change as lenders pull back from fiscal interventions. As more CLOs are issued, the problem grows worse: more securitizations create more demand for loans, higher demand for credit, and less monitoring. This is likely to drive up the risk of default in a manner correlated with the timing of the loan. The overall increase in the correlation of default risks might be small, and it is beyond the scope of this Article to attempt to quantify it. But even if the effect of this correlation is small, it can have an extremely large impact on CLOs.

\section{Ways to Address the Governance Effect of Securitization}

A number of options exist to address these issues. I touch upon some of them here, although a more detailed analysis must be left for future work. I caveat that more research is needed to determine the full extent of this problem and to answer whether it will prove to be persistent over time or whether other market forces will move in to compensate. But it is nonetheless useful to begin considering ways this problem might be addressed.

One possible means to alleviate the problem would be a modified version of the skin-in-the-game rule the SEC created for securitizations. One relatively simple modification would require originating lenders to keep an interest in Term A or

331 Fin. Stability BD., Vulnerabilities, supra note 2, at 4-5, 32-33.

332 Id. 
revolving facility loans for the duration of any institutional loans made to the same borrower. Currently, Term A loans have shorter maturities than institutional tranches, and originating lenders sometimes sell their interest in the loans before maturity. ${ }^{333}$ Under the new rule, Term A loans would be required to have the same maturities as institutional tranches and originating lenders would be required to hold their tranches until they matured. This would ensure that these lenders would have incentives to monitor and intervene in borrowers' governance for the duration of institutional loans, to the extent that institutional lenders participating in the loans lacked such incentives. This rule could be extended to loans originated by non-bank lenders as well, requiring any arranger to keep a large enough interest in the loan such that they would retain their monitoring incentives. One problem with this change is that, while it may address the incentive problem, it does not address the bargaining power problem. That is, even if lenders have incentives to monitor, they may lack the bargaining power to enforce change if the supply of credit remains strong and borrowers are able to walk away from over-demanding creditors.

Another possibility that addresses both incentives and bargaining power would be to regulate debt contracts directly. This could be done through a regulatory mandate regarding the content of contracts, or through an expansion of the scope of corporate directors' duties to require that debt contracts include full sets of monitoring covenants. 334

The Federal Reserve, along with a number of other regulators, issued guidance on leveraged lending in 2013 that attempted to regulate market practices. ${ }^{335}$ The guidance primarily related to underwriting practices and limited the amount of leverage a bank could allow borrowers to have. ${ }^{336}$ The guidelines thus helped address the adverse selection and risk

333 Id. at 32.

334 The possibility of expanding the scope of directors' fiduciary duties as they relate to debt contracts is similar to one that has been proposed in a parallel context. See Rock, supra note 304, at 1978-81.

335 See Interagency Guidance on Leveraged Lending, 78 Fed. Reg. 17,766 (Mar. 22, 2013).

336 Id. 
taking problems that loan markets generate, and promoted monitoring as well. This guidance has largely been walked back by financial regulators, ${ }^{337}$ and due to the entry of unregulated shadow banks, while being enforced the guidelines had limited effect in limiting risky lending. ${ }^{338}$ Drafting rules (not guidance ${ }^{339}$ ) covering all types of lending institutions might help to correct the problems described in this Article. Regulations defining minimally acceptable loan terms might substitute for lenders' loss of bargaining power at the initial contracting phase by requiring monitoring covenants by fiat. If all lending institutions were covered, such regulations would also help offset lenders' loss of bargaining power at the covenant violation phase, because it would reduce borrowers' ability to seek better terms from other lenders, thus reducing their leverage. A drawback of this proposal is that government interference with private lending relationships can lead to unforeseen inefficiencies in the lending market. It would also be difficult to prescribe the precise monitoring covenants that would be required to be included, as each borrower might have idiosyncratic indicators that warrant monitoring, and each lender may have different preferred metrics of borrower health. Definitions of metrics can also be manipulated. Writing regulations that accommodate the different preferences and definitions a contract might use would be difficult and would result in greater regulatory complexity. Nonetheless, such tasks have been accomplished in other areas, and with the participation of industry stakeholders reasonable standards can be set.

Yet another possibility is that covenants could be required to include full monitoring powers, but also duties to monitor, thus mitigating the non-governance incentive problem. The scope of the monitoring duties might vary, and standards for such monitoring duties could be set at different levels of

337 See Supervisory Statements...and Leveraged Lending Guidance?, LoAN Syndications \& TrAding Ass'N (Sept. 13, 2018), https://www.lsta.org/news-resources/supervisory-statementsand-leveraged-lending-guidance/ [https://perma.cc/AL56-4FBF].

338 See Berlin, supra note 95.

339 See Supervisory Statements...and Leveraged Lending Guidance?, supra note 337. 
stringency. At the more benign end, lenders would simply be required to monitor and intervene, if necessary, to ensure financial solvency. On the more stringent end, these covenants might require lenders to account for and limit agency costs vis-à-vis shareholders where possible, in order to limit the conflict of interests between themselves and stockholders. Thus, if lenders decide to intervene to push for a change in financial policies or force a change in management, they would do so with the interests of shareholders in mind.

There are problems with such proposals as well. Imposing additional duties on the lender-debtor contractual relationship opens up uncertainty in the performance of those duties. It may become harder for courts to determine, ex-post, what the right course of action is in a given situation. Perhaps more importantly, it would be harder for parties to predict, ex-ante, what a court might do in enforcing such rights. ${ }^{340}$ This would give rise to uncertainty, effectively raising contracting costs for both companies and lenders.

However, this increase in costs is a problem only insofar as it is not offset by the benefits of such a proposal. As already discussed, firms and society as a whole benefit greatly from lender monitoring and governance intervention. Moreover, the kinds of activities that would meet this expanded fiduciary duty would not be uncharted territory. They would essentially encompass the same actions that lenders and firms were doing before the lending market disincentivized them from doing so. The parties would, in effect, be doing what they did before, which would greatly mitigate any uncertainties about what their duties entailed. Thus, the usual problems inherent in fiduciary duties and enforcing contract standards would be greatly mitigated, and arguably would be worth the benefits they engender.

340 See Triantis, supra note 303, at 2045-46 (explaining how standards-based contracts can "raise back-end enforcement costs, especially the costs of litigation and judicial error in applying the standard"). 


\section{CONCLUSION}

Amidst the debates about the actions of large institutional shareholders in corporate governance, important stakeholders like lenders sometimes receive less attention. As this Article documents, lenders' important role in corporate governance has begun to erode with respect to companies who may benefit most from it. As the credit market has heated up and corporate borrowers have gained outsized leverage in negotiations with lenders, problematic practices have begun to emerge. The change in bargaining power driven by CLOs is increasingly associated with weakening lender protections, but an unintended consequence is the weakening of lenderdriven governance intervention. This may create problems for individual companies, and it may also lead to increased risk for the financial products driving this trend in the first place.

A better appreciation of the ways that corporate governance and the financial system affect each other is helpful to understanding the problems with each. The financial system, and the regulation that constrains it, impacts the interactivity that corporate governance depends upon. At the same time, the quality of corporate governance affects the assumptions that financial innovation and regulation are built upon. Misunderstanding this endogenous relationship between the financial system and corporate governance has resulted in the degradation of an important check in the system of corporate checks and balances, to which attention has scarcely been paid.

The complex problem of corporate non-governance does not lend itself to easy solutions but understanding the source of the problem is a first step in thinking through possible fixes. The goal should be to align actors' incentives with the roles each should play in appropriate governance, and a start would be to facilitate intervention that gives parties a reason to view their financial assets as a relationship, as much as an investment. 